\title{
Acritarchs from the Lower Cambrian Buen Formation in North Greenland
}

\author{
G E U S
}

Report file no.

22316

Gonzalo Vidal and John S. Peel

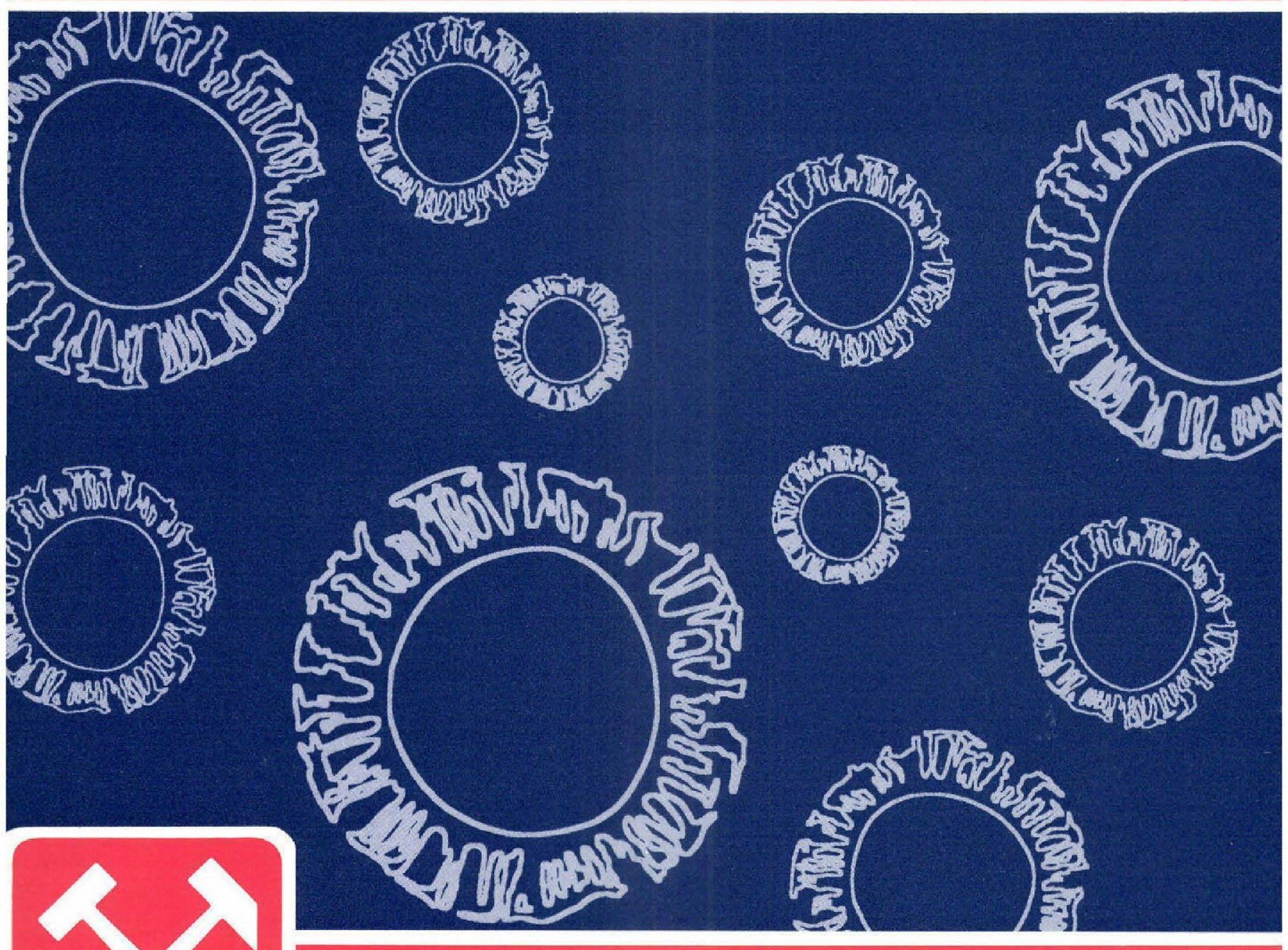

GRØNLANDS GEOLOGISKE UNDERSØGELSE

GGU Bulletin 164

1993 
GRØNLANDS GEOLOGISKE UNDERS $\emptyset$ GELSE Bulletin 164

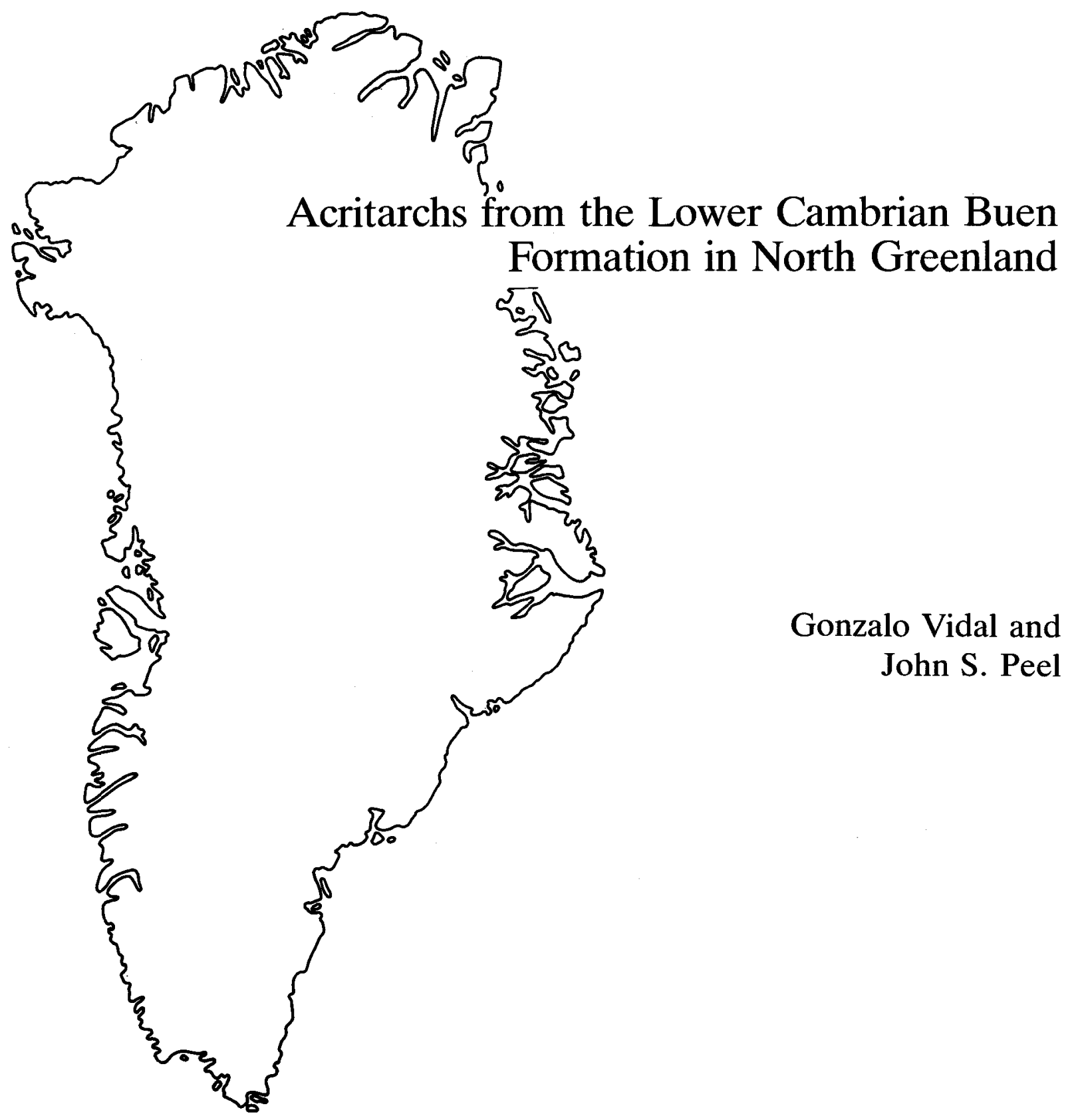


Vidal, G. \& Peel, J. S. 1993: Acritarchs from the Lower Cambrian Buen Formation in North Greenland. Bull. Grønlands geol. Unders. 164, 35 pp.

Acritarchs (organic-walled phytoplankton) are described from the siliciclastic rocks of the Buen Formation. A total of 52 form taxa are reported from a small number of extremely fossiliferous samples from the deeper shelf portion of the formation. The preservation of acritarchs is excellent and, in the light of their abundance, the taphonomy and palaeobiology of the Buen Formation are discussed. Three new acritarch form taxa are erected and two more, obviously also new, are left under open nomenclature. Large-size acanthomorphic acritarchs represented by extremely rare finds of two new taxa (Comasphaeridium? densispinosum $\mathrm{n}$. sp. and Comasphaeridium longispinosum n. sp.) are recorded for the first time in Lower Cambrian strata. Large acanthomorphs are otherwise important in Neoproterozoic strata and the significance of the present finds is discussed. The remaining acritarchs are known from numerous world-wide earlier occurrences. Comparisons are particularly important and relevant with classical Lower Cambrian rock successions in Baltoscandia, various areas of the East European Platform, Svalbard, Scotland and North-East Greenland. In all, the recovered acritarch assemblage conclusively confirms the previously proposed late Early Cambrian age for the Buen Formation, most likely corresponding to the $\mathrm{He}$ liosphaeridium dissimilare - Skiagia ciliosa (= Vergale 'horizon') and perhaps the Volkovia dentifera - Liepaina plana (= Rausve 'horizon') acritarch zones in the East European Platform and counterparts in Baltoscandia.

\section{Authors' addresses:}

G. V., Institute of Earth Sciences - Micropalaeontology, Uppsala University, Norbyvägen 22, S-751 22 Uppsala, Sweden.

J. S. P., Geological Survey of Greenland, Øster Voldgade 10, DK-1350 Copenhagen K, Denmark. Present address: Institute of Earth Sciences - Dept of Historical Geology and Palaeontology, Uppsala University, Norbyvägen 22, S-751 22 Uppsala, Sweden.

\section{Grønlands Geologiske Undersøgelse Ujarassiortut Kalaallit Nunaanni Misissuisoqarfiat Geological Survey of Greenland}

The Geological Survey of Greenland (GGU) is a research institute affiliated to the Mineral Resources Administration for Greenland (MRA) within the Danish Ministry of Energy. As with all other activities involving the non-living resources in Greenland, GGU's investigations are carried out within the framework of the policies decided jointly by the Greenland Home Rule Authority and the Danish State. 


\section{Contents}

Dansk sammendrag - Imaqarnersiuineq $\ldots \ldots \ldots \ldots \ldots \quad 4$

Introduction. . . . . . . . $\ldots \ldots \ldots \ldots \ldots \ldots \ldots, \quad 5$

Geological framework ................... 5

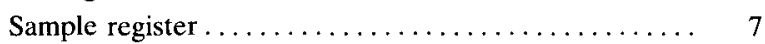

Material and methods $\ldots \ldots \ldots \ldots \ldots \ldots \ldots \ldots \ldots$

Acritarch preservation................... 9

Taphonomy and palaeobiology $\ldots \ldots \ldots \ldots \ldots \ldots . . \ldots$

Large acanthomorphic acritarchs............. 11

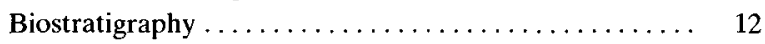

Conclusions .......................... 13

Taxonomy ........................... 15

Archaeodiscina umbonulata Volkova, 1968 ....... 15

Asteridium Moczydłowska $1991 \ldots \ldots \ldots \ldots \ldots \ldots .15$

Asteridium lanatum (Volkova, 1969)

Moczydłowska, 1991 ..................... 15

Asteridium ordensis (Downie, 1982), comb. nov. .... 15

Asteridium tornatum (Volkova, 1968)

Moczydłowska, $1991 \ldots \ldots \ldots \ldots \ldots \ldots \ldots \ldots . \ldots 17$

?Celtiberium geminum Fombella, 1977......... 17

Comasphaeridium sp. A Downie, $1982 \ldots \ldots \ldots \ldots .17$

Comasphaeridium agglutinatum Moczydłowska, 1988. 19

Comasphaeridium mackenziana Baudet, Aitken \&

Vanguestaine, 1989 ...................

Comasphaeridium molliculum Moczydłowska \&

Vidal, 1988.

Comasphaeridium? densispinosum Vidal n. sp. ......

Comasphaeridium longispinosum Vidal n. sp. .......

Comasphaeridium strigosum (Jankauskas)

Downie, 1982

Comasphaeridium cf. strigosum (Jankauskas)

Downie, $1982 \ldots \ldots \ldots \ldots \ldots \ldots \ldots \ldots \ldots \ldots . \ldots \ldots$

Cymatiosphaera postii (Jankauskas, 1976)

Jankauskas, $1979 \ldots \ldots \ldots \ldots \ldots \ldots \ldots \ldots \ldots 21$

Cymatiosphaera sp. .................. 21

Dictyotidium Eisenack, 1955 emend. Staplin, $1961 \ldots 21$

Dictyotidium perforatum Vidal n. sp........... 21

Elektoriskos sp. A ...................... 23

Fimbriaglomerella Loeblich \& Drugg, 1968 ...... 23

Globosphaeridium cerinum (Volkova)

Moczydłowska, 1991

Goniosphaeridium primarium (Jankauskas)

Downie, 1982
Goniosphaeridium sp. A................. 23

Goniosphaeridium varium (Volkova, 1969)

Downie, $1982 \ldots \ldots \ldots \ldots \ldots \ldots \ldots \ldots \ldots \ldots .23$

Goniosphaeridium volkovae Hagenfeldt, $1989 \ldots \ldots .25$

Granomarginata squamacea Volkova, 1968....... 25

Heliosphaeridium sp................. 25

Heliosphaeridium coniferum (Downie, 1982)

Moczydlowska, $1991 \ldots \ldots \ldots \ldots \ldots \ldots \ldots \ldots .25$

Heliosphaeridium dissimilare (Volkova, 1969)

Moczydlowska, $1991 \ldots \ldots \ldots \ldots \ldots \ldots \ldots \ldots 25$

Heliosphaeridium lubomlense (Kirjanov, 1974)

Moczydłowska, $1991 \ldots \ldots \ldots \ldots \ldots \ldots \ldots \ldots .25$

Heliosphaeridium notatum (Volkova, 1969)

Moczydłowska, $1991 \ldots \ldots \ldots \ldots \ldots \ldots \ldots \ldots .25$

Heliosphaeridium obscurum (Volkova, 1969)

Moczydłowska, $1991 \ldots \ldots \ldots \ldots \ldots \ldots \ldots \ldots \ldots 27$

Leiosphaeridia Eisenack, 1958 emend. Downie \& Sarjeant, $1963 \ldots \ldots \ldots \ldots \ldots \ldots \ldots \ldots \ldots \ldots 27$

Leiovalia tenera Kirjanov, $1974 \ldots \ldots \ldots \ldots \ldots \ldots .27$

Lophosphaeridium dubium (Volkova, 1968)

Moczydlowska, $1991 \ldots \ldots \ldots \ldots \ldots \ldots \ldots \ldots . \ldots 27$

Lophosphaeridium tentativum Volkova, 1968 ...... 27

Lophosphaeridium truncatum Volkova, $1969 \ldots \ldots .27$

Lophosphaeridium sp.................. 29

Multiplicisphaeridium dendroideum

(Jankauskas, 1976) ....................... 29

Pterospermella Eisenack, 1972 ............... 29

Retisphaeridium dichamerum Staplin, Jansonius \&

Pocock, $1965 \ldots \ldots \ldots \ldots \ldots \ldots \ldots . \ldots \ldots . \ldots . \ldots 29$

Skiagia Downie, 1982 .................... 29

Skiagia ciliosa (Volkova, 1969) Downie, 1982 . . . . 29

Skiagia compressa (Volkova, 1968) Downie, 1982 . . . 29

Skiagia orbiculare (Volkova, 1968) Downie, 1982 ... 31

Skiagia ornata (Volkova, 1968) Downie, $1982 \ldots \ldots . \quad 31$

Skiagia scottica Downie, 1982 . . . . . . . . . . . 31

Tasmanites bobrowskae Ważyńska, $1967 \ldots \ldots \ldots \ldots . \quad 31$

Tasmanites tenellus Volkova, $1968 \ldots \ldots \ldots \ldots \ldots \ldots . . \ldots$

Tasmanites volkovae Kirjanov, $1974 \ldots \ldots \ldots \ldots \ldots .31$

Trachysphaeridium timofeevi Vidal, 1976......... 31

Acknowledgements ................... 33

References........................ 33 


\section{Dansk sammendrag}

Dette arbejde beskriver acritarcher (fytoplankton med organisk vag) fra Buen Formationen (nedre Kambrium) i Nordgrønland. I alt rapporteres der om 52 arter fra få men særdeles fossilrige prøver, der repræsenterer den dybere del af shelfen i Buen Formationen. På baggrund af det store indhold af velbevarede acritarcher diskuteres formationens tafonomi og palæobiologi. Tre nye arter af acritarcher opstilles, mens to andre, tydeligvis også nye, placeres under åben nomenklatur. Store acantomorfe acritarcher er for første gang registreret i lag fra nedre Kambrium. Disse former er ellers kun beskrevet fra neoproterozoiske aflejringer. De resterende acritarcher kendes fra talrige tidligere forekomster verden over. Det er især vigtigt at sammenligne med de klassiske aflejringer fra nedre Kambrium i Baltoscandia, forskellige områder på den østeuropæiske platform, Svalbard, Skotland og Nordøstgrønland. Acritarch-sammensætningen bekræfter fuldtud den tidligere foreslåede datering af Buen Formationen til den sene del af tidlig Kambrium, højst sansynligt svarende til Heliosphaeridium dissimilare - Skiagia ciliosa (= Vergale 'horizon') og måske Volkovia dentifera - Liepaina plana (= Rausve 'horizon') acritarch-zonerne på den østeuropæiske platform og tilsvarende zoner i Baltoscandia.

\section{Imaqarnersiuineq}

Nalunaarusiami uvani imaani naasuaqqat, acritarchit, Avannaarsuani ujaqqani immikkoortuni Buen Formationimeersut ukiut immikkoortut Kambriumip aallartinnerani pinngorsimasut eqqartorneqarput. Ujaqqani amerlanngikkaluartutuni naasuaqqanilli ujaranngorsimasunik amerlaqisunik akulinni, architarchit immikkoortut 52-t siumorneqarsimapput, taakkulu Buen Formationip atsinnerusortaani nassaarineqarsimapput. Architarcherpassuit ujaranngorsimagaluarlutik ilusaat allanngorsimanngitsut tunngavigalugit qangarsuaq sumi inuusimanerat eqqartorneqarpoq. Architarchit immikkoortut nutaat pingasut suunerat aalajangerneqarsimavoq, allalli marluk qularnanngitsumik nutaajusut suli erseqqissumik taaguuserneqarsimanngillat. Aatsaat siullerpaamik acritarchit annertoqisut ukiut 570 milliunit matuma siornatigut pinngorsimasut allaaserineqarput, taamaattut ujaqqani pisoqaanerusuni taamaallat siornatigut allaaserineqartarsimagamik. Acritarchit sinneri silarsuarmi ujaqqani allarpassuarni siornatigut allaatigineqarsimasuni ilisimaneqarput. Ujaqqat architarchiqarfiusut pingaarnerit 570 milliunit missaanni pisoqaassusillit Baltoscandiami, Europami kangilliup nunavissuani, Svalbardimi, Skotlandimi Tunumilu Avannaarsuani sanilliussallugit pingaartorujussuuvoq. Architarchit assigiinngitsorpassuit ataatsimoortut tunngavigalugit ujaqqat imikkoortut Buen Formationip pisoqaassusaasa Kambriumip aallartinnerani pinngorsimasutut aalajangerneqarsimanerat maannakkut erseqqissumik uppernarsineqarsimavoq. 


\section{Introduction}

The organic-walled envelopes of presumably motile and/or encysted life stages of Early Palaeozoic protists (Dale, 1977; Tappan, 1980) are among the most abundant fossils in shallow to moderately deep shelf deposits (Downie, 1973). Near the Proterozoic/Phanerozoic boundary eukaryotic plankton underwent a radiation (Moczydłowska \& Vidal, 1986) comparable in magnitude to that formerly reported among ichnofossils (Crimes, 1987) and skeletised faunas (Conway Morris, 1987). Assemblages of acritarch taxa which in a geologic perspective, arose and declined rapidly, are becoming increasingly well-known in numerous regions (see Moczydłowska, 1991 for a recent review). Together with shelly faunas, they provide the basis for increasingly refined biostratigraphy which allows the correlation of
Early Phanerozoic radiation events. In addition, organic-walled phytoplankton provide valuable information about conditions of deposition and organic diagenesis.

In this paper following previous preliminary reports (Vidal \& Peel, 1984; Moczydłowska \& Vidal, 1986) we deal with the palaeobiology, taxonomy and biostratigraphy of the abundant acritarchs of the Buen Formation of North Greenland. One additional point of interest circles around the taphonomic significance of acritarchs in the Buen Formation in the light of the previously reported occurrence of an exceptionally preserved fauna of poorly skeletised macrofossils from the same formation (Conway Morris et al., 1987; Conway Morris \& Peel, 1990; Peel, 1990; Peel et al., 1992).

\section{Geological framework}

The Buen Formation forms part of a southern shelf sequence within the Lower Palaeozoic Franklinian Basin succession of the Canadian Arctic Islands and northern Greenland (Higgins et al., 1991; Surlyk, 1991). This carbonate-dominated shelf sequence unconformably overlies crystalline basement of the Greenland Shield and Proterozoic sedimentary basins to the south. To the north, the shelf sequence passes into an equivalent deep-water trough sequence but the northern margin of this Franklinian Basin succession is poorly constrained.

The Buen Formation contrasts with most units within the Franklinian shelf sequence of northern Greenland in being composed of siliciclastic sediments. This siliciclastic interval can be traced east-west across northern Greenland, either as the Buen Formation itself (Fig. 1) or as the correlative Dallas Bugt Formation and Humboldt Formation of the area around Kane Basin, to the west (Peel 1982; Peel \& Christie, 1982).

In central and eastern North Greenland (Fig. 1) the Buen Formation overlies marine platform carbonate sediments of the Portfjeld Formation. The latter formation is poorly fossiliferous but has yielded the cyanobacteria Spirellus Jiang, 1982, Obruchevella Reitlinger, 1948 and Jiangispirellus Peel, 1988 of probable Early Cambrian age (Peel, 1988).

The Buen Formation is overlain by a progradational shelf sequence referred to the Brønlund Fjord Group and the overlying Tavsens Iskappe Group throughout most of central and eastern North Greenland. Strata assigned to these groups form a complex of prograding, diachronous carbonates and subordinate siliciclastic sediments. Shelly macrofossils are conspicuous at many horizons within the two groups and indicate an age from late Early Cambrian to earliest Ordovician.

The Buen Formation varies in thickness from about $425-500 \mathrm{~m}$ in its southern outcrop in Peary Land but thins to about half this amount in the small outcrops in northern Freuchen Land and northern Wulff Land (Fig. 1). Farther north, the succession thickens greatly as the formation grades into the turbidite trough sequence of the Polkorridoren Group. Typically, the formation can be divided into a lower sandstone-dominated unit and an overlying recessive unit dominated by mudstones. The sandstone-dominated unit is most prominent in southern outcrops from Wulff Land to southern Peary Land but mudstones dominate in north-east Peary Land and outcrops along the northern coast of Greenland, to the west. The characteristic transition from sandstonedominated inner shelf deposits to finer grained outer shelf deposits reflects a regional rise in sea level within Buen time.

A section through the formation at its type locality is shown in Fig. 2 and most samples processed for acritarchs in the present study were either derived from this section or from outcrops close by. The lower sandstonedominated unit contains strata interpreted as inner shelf 


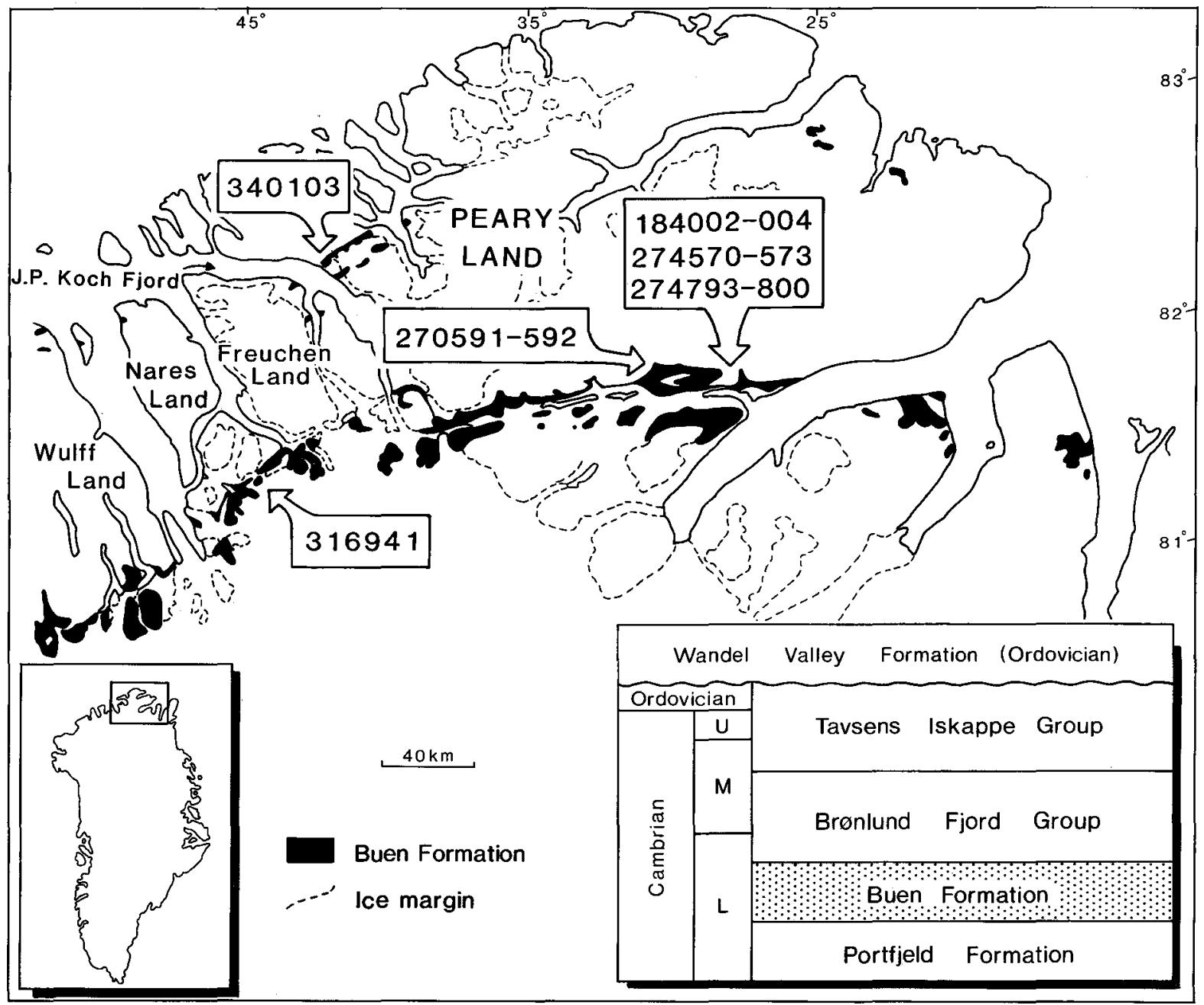

Fig. 1. Outcrops of the Buen Formation in central North Greenland showing the derivation of fossiliferous samples.

and tidal deposits. The abrupt sedimentological change from sandstone domination to mudstone at about $270 \mathrm{~m}$ above the base of the section indicates maximum transgression of the shelf and the establishment of a deep shelf environment. Subsequent strata are mudstonedominated, with thin beds of storm deposited sandstones; they represent a sequence shallowing to inner shelf environments but not as shallow as the sandstonedominated lower unit of the formation. A detailed sedimentary profile through the lower part of the formation in the un-named land area south of Nares Land (locality for GGU 316941 in Fig. 1) was presented by Bryant \& Pickerill (1990, fig. 2).

The lower sandstone-dominated unit of the Buen Formation in southern outcrops has not yielded macrofossils, although trace fossils have been described by Bryant \& Pickerill (1990). In the vicinity of the type locality in southern Peary Land, well preserved and abundant macrofossils occur within the deep shelf mudstones from the same samples as those yielding acritarchs in the present investigation (e.g., GGU samples 184002-184004; GGU 270591-270592). Olenellacean trilobites include Olenellus hyperboreus (Poulsen, 1974), associated with hyolithids, bradoriids. Pelagiella, Hyolithellus and inarticulate brachiopods (cf. Poulsen, 1974; Palmer \& Peel, 1979). Olenellus is also reported from the highest beds of the formation in eastern Peary Land (Palmer \& Peel, 1979), while Bergström \& Peel (1988) described trace fossils from the same interval in southern Peary Land.

In north-western Peary Land (Fig. 1, GGU 340103) outer shelf mudstones in the lower part of the Buen Formation have yielded a rich fauna of poorly skeletised macrofossils associated with the nevadiid olenellacean Buenellus higginsi Blaker, 1988. The fauna is dominated by arthropods and worms, the latter including artic- 
ulated halkieriids (Conway Morris et al., 1987; Conway Morris \& Peel, 1990; Peel, 1990; see also Blaker, 1988). Acritarchs have not been recovered from this locality.

\section{Sample register}

The relative stratigraphic position of samples processed for acritarchs is indicated in Fig. 2.

GGU 184002-184004: Buen Formation at Brilles $\varnothing$, east side of the valley of Børglum Elv, southern Peary Land, a few kilometres north-east of the type locality of the formation (cf. Figs 1, 2). Samples collected by J. S. Peel, 1974.

GGU 270591, 270592: Buen Formation on the northern side of Sæterdal, southern Peary Land, about $20 \mathrm{~km}$ west of the type locality (cf. Figs 1, 2). Samples collected by J. S. Peel, 1978.

GGU 274793-274800, 274570-274573: Buen Formation at its type locality, north side of Jørgen Brønlund Fjord, immediately west of the mouth of B $\emptyset$ rglum Elv in southern Peary Land (Figs 1, 2). Samples collected by H. A. Armstrong and J. R. Ineson, 1980.

GGU 340103: Lower Buen Formation, Sirius Passet, northwest Peary Land (Fig. 1). Collected by S. Conway Morris and J. S. Peel, 1989.

GGU 316941: $54.8 \mathrm{~m}$ above the base of the Buen Formation, un-named land area south of Nares Land (see Figs 1, 2). Collected by I. D. Bryant, 1984 (see Bryant \& Pickerill, 1990).

Fig. 2. Section through the Buen Formation at its type locality, west of the mouth of Børglum Elv on the northern shore of Jørgen Brønlund Fjord, southern Peary Land, showing the location of GGU samples. Numbers in brackets indicate samples collected at other localities (see Fig. 1) and correlated with the type section. The succession shows two shallowing-up cycles. The lower part of the section $(0-270 \mathrm{~m})$ represents an inner shelf succession characterised by storm beds which are succeeded at about $120 \mathrm{~m}$ by sediments showing a tidal influence. Deep shelf mudstones $(c .270-325 \mathrm{~m}$ ) represent the period of maximum transgression of the shelf; subsequent sediments indicate shallowing to inner shelf conditions, but not as shallow as the lower cycle.

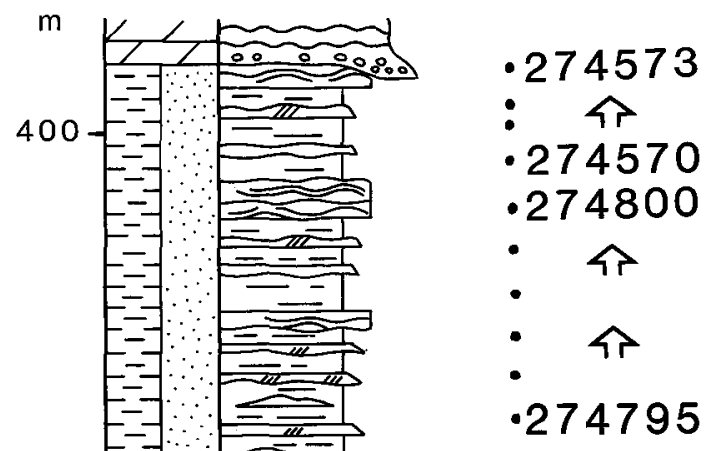

(184002-4)

$(270591,2)$
274794

274793

$?(316941)$ 


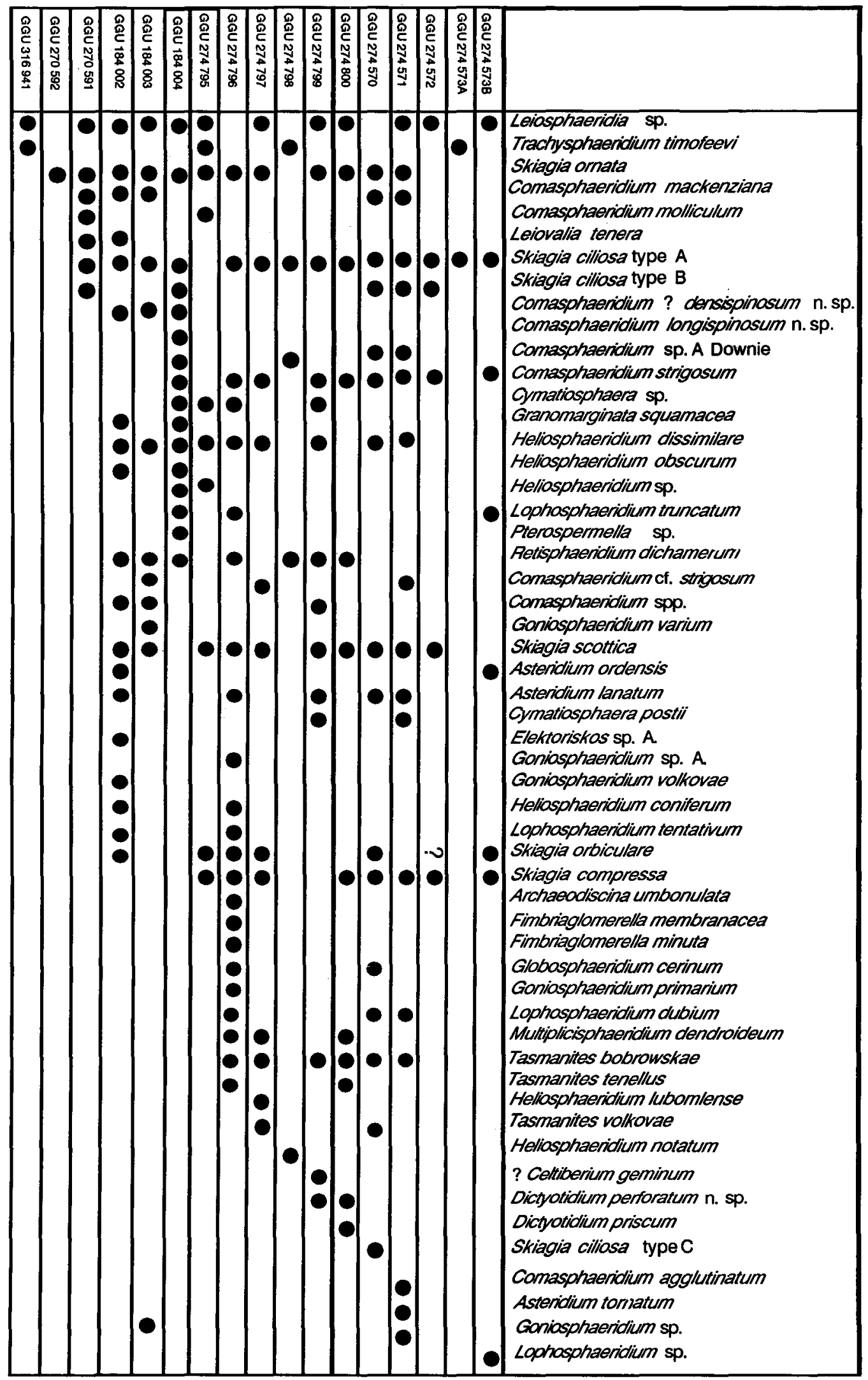

Fig. 3. Chart showing the occurrence of acritarchs in processed samples from the Buen Formation. 


\section{Material and methods}

Spot samples and samples collected from stratigraphic sections through the Buen Formation are included in this study. Acid-resistant organic-walled residues were isolated from a total of 20 samples using a method fully described by Vidal (1988). Sixteen samples proved fossiliferous, a figure that by any accounts is to be considered as a very high yield.

\section{Acritarch preservation}

The preservation of acritarchs and other organic microfossils in the investigated samples is generally good to excellent. The most productive samples (e.g. GGU samples 184002-184004, 274570-274572, 274795274799) are rich in yellowish to brown, granular or flaky, organic sapropel. Compaction and flattening of microfossils is moderate and certain samples (notably GGU 184004 and 274571, 274796, 274797) yielded three-dimensionally preserved acritarchs. The reason for this is unclear, but comparable preservation has been observed elsewhere in Lower Cambrian rocks with high phosphate contents (Mcczydłowska \& Vidal, 1992). It cannot be excluded that the investigated black mudstones and shales may include early diagenetic phosphatised portions, thus accounting for the unusually good preservation of acritarchs. but such intervals have not been detected.

The colour of acritarchs, cyanobacterial microfossils and amorphous organic matter ranges from light yellow to brown and this suggests thermal alteration index (TAI) values around 2 to $2+$ (immature to mature; Pearson, 1984). These data are in agreement with a thermal alteration corresponding to temperatures between 50 and $<150^{\circ} \mathrm{C}$. Exceptionally, one sample (GGU 340103) of thinly laminated black pyritous shale yielded dark-grey to black bacterial microfossils and sapropel-like organic debris indicating thermal alteration (TAI $4-$ to 4 ) in the order of $200^{\circ} \mathrm{C}$ or higher. This sample, collected from the locality in Sirius Passet, northern Peary Land, which yield the poorly skeletised fauna described by Conway Morris et al. (1987) and Conway Morris \& Peel (1990) lies on the southern margin of the North Greenland fold belt (Dawes, 1976; Higgins et al., 1991). The higher degree of thermal alteration reflects metamorphism associated with the fold belt.

\section{Taphonomy and palaeobiology}

It appears possible that the accumulation of Early Palaeozoic acritarchs may have followed patterns comparable to those of the geologically more recent phytoplankton groups (Knoll, 1985), such as dinoflagellates (Evitt, 1985; Vidal \& Nystuen, 1990a).

Despite generally low Total Organic Carbon (TOC) values around $0.1 \%$, (except the above mentioned sample 340103 with TOC $2.0 \%$ ) finely laminated and carbon-rich rocks from the Buen Formation yield large amounts of organic sapropel and acritarchs that seem to bear witness of quiet water conditions and slow deposition. Thus for example, sapropel A is believed to form in low energy lacustrine or marine environments where abundant organic matter accumulates under restricted circulation and dysaerobic conditions (Staplin et al., 1973, cited in Venkatachala, 1981).
As pointed out above (see Geological framework) an abrupt sedimentological change is observed from the lower sandstone to the upper mudstone-dominated portion of the Buen Formation. These changes correlate well with the recorded lack, respectively abundance, of macrofossils and microfossils. Thus, except for ichnofossils (Bryant \& Pickerill, 1990), the dominantly arenaceous portions of the investigated section (Fig. 2) are barren, whereas the deeper shelf mudstones (samples GGU 274796, 274797, 274800, 274570; Figs 2, 3) yield abundant acritarchs (Vidal \& Peel, 1988); rich shelly faunas are best known from the deepest part of the succession (e.g. GGU samples 184002-4; Poulsen, 1974; Palmer \& Peel, 1979). Furthermore, the frequency of discrete palynomorph taxa varies considerably in the investigated samples and certain taxa (e.g. 


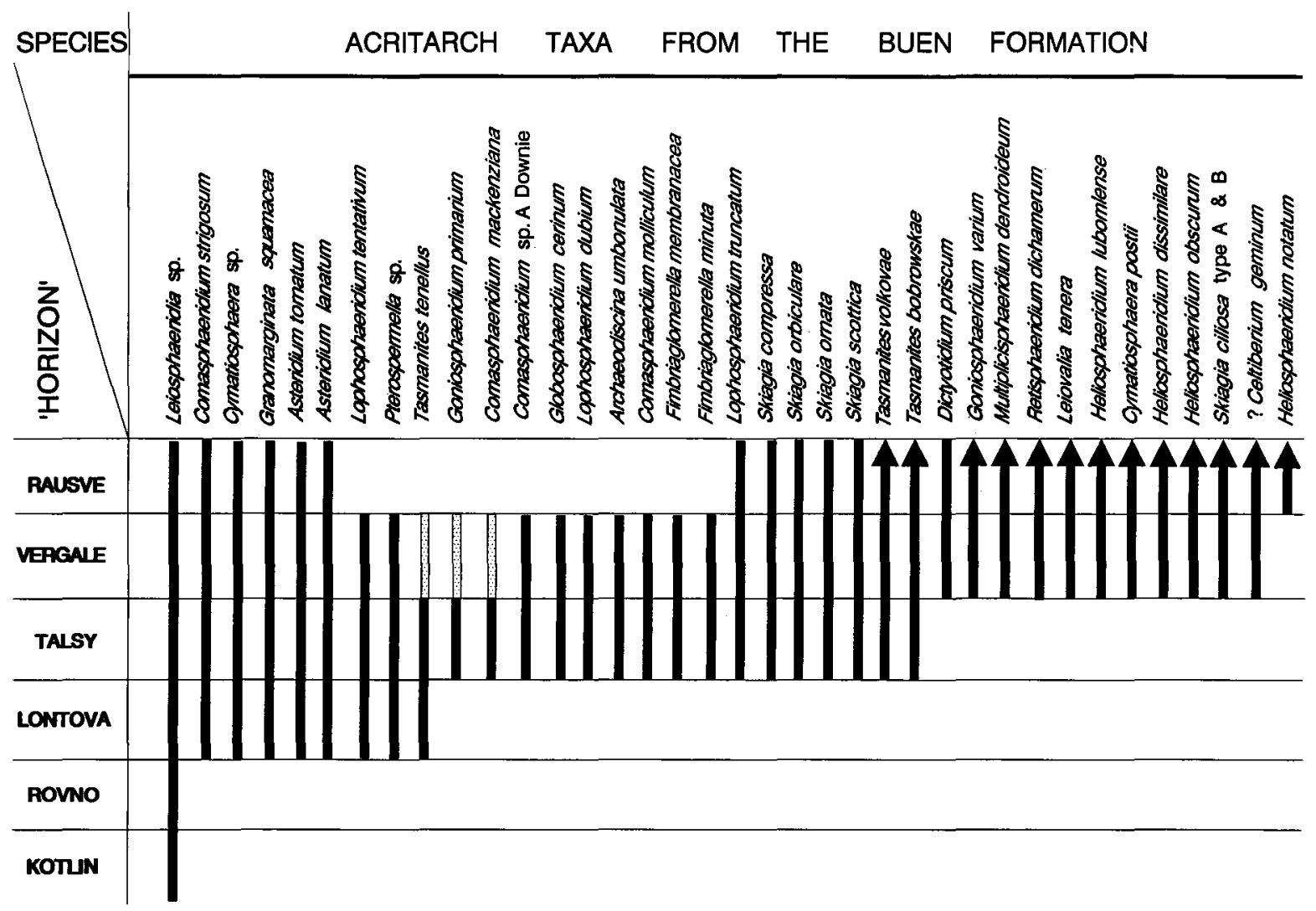

Fig. 4. Stratigraphic ranges of acritarchs in samples from the Buen Formation according to previous occurrences in various parts of the East European Plątform (Volkova et al., 1983; Moczydłowska, 1991). Taxa with stratigraphically poorly constrained ranges are omitted.

Skiagia ornata, S. ciliosa, S. scottica form the bulk of the total palynomorph population in most samples. In terms of the taxonomic diversity among acritarchs, the Buen Formation is roughly comparable to the diversity recorded in time-equivalent Early Cambrian rock units in Baltoscandia (Eklund, 1990; Hagenfeldt, 1989; Moczydłowska \& Vidal, 1986; Moczydłowska, 1991).

Lower Cambrian units in Baltoscandia represent deposition in pericratonic basins under generally shallow water conditions as demonstrated by the abundance of sedimentary rocks displaying various features indicating shallow shelf to littoral deposition (cf. Eklund, 1990; Vidal \& Nystuen, 1990b). Although abundant phytoplankton can be recovered from generally shallow marine sequences (Moczydłowska \& Vidal, 1992), a general trend towards decreasing taxonomic diversity is pervasive in littoral sequences (Vidal \& Nystuen, 1990a; Palacios \& Vidal, 1992) as compared to contemporaneous deeper shelf settings. Depositional settings and post-burial degradation processes are of extreme importance for the preservation potential of delicate organicwalled remains (Butterfield, 1990).
Rocks of the Buen Formation at Sirius Passet in north-western Peary Land (GGU 340103 in Fig. 1) yield a fauna of arthropods, worms, sponges and halkieriids (Conway Morris et al., 1987; Conway Morris \& Peel, 1990; Peel, 1990; Peel et al., 1992). One single processed sample (GGU 340103) from this important locality yielded only thermally altered possibly bacterial microfossils attributed to Sphaerocongregus variabilis Moorman, 1974 that have been interpreted as probable cyanobacteria (Knoll \& Swett, 1985; Moorman, 1974; Mansuy \& Vidal, 1983) or photosynthetic anoxygenic bacteria (Vidal \& Nystuen, 1990a). Interestingly, and parallel to well-studied dysaerobic late Neoproterozoic basins in Spain (Palacios, 1989) and Baltoscandia (Vidal \& Nystuen, 1990a), acritarchs are also absent from this fossiliferous Buen sample (GGU 340103). Other records of exceptionally preserved Cambrian faunas share with the Buen Formation the probably significant feature of occurring in 'deeper water shales' (Conway Morris, 1987). A detailed study of organic, non-mineralising organisms in the Burgess Shale (Butterfield, 1990) revealed that the Burgess Shale, contrary to the present 
case, yields abundant leiosphaerid and rare papillose (Butterfield, 1990) and small spiny acritarchs (Vidal, unpublished observation). Furthermore, Butterfied (1990) concluded that carbon isotopic values for the Burgess Shale reflect normal conditions. No such data are available for the Buen Formation. The investigated Buen sample comes from a succession where bioturbation is present in certain beds, but the soft bodied fauna is collected from laminated horizons with only a few horizontal burrows in part of the section where bioturbated and non-bioturbated horizons alternate. It can be concluded that the presence of abundant organic matter and pyrite in the investigated sample from north-western Peary Land and the recovered biotas are consistent with sparse bioturbation, enhanced carbon burial and perhaps oxygen-depleted bottom water.

In this context, the contrasting abundance of acritarchs in the mudstone-dominated deeper shelf portion of the Buen Formation in more southern outcrops is here seen as indicating a preserved sample of accumulated encysted and/or motile life stages of algal protists. This feature may indicate accumulation in organic-rich sediments overlain by nutrient-rich oxic waters in the mixed layer or, alternatively represent the accumulated phytoplankton that occupied productivity 'hot spots' in denitrified anoxic waters along the narrow chemical gradients at the boundary of the oxygen-minimum zone (Berry et al., 1989). The latter has existing parallels in blooms produced by dinoflagellates under conditions suitable to denitrification (Eppley et al., 1969).

Proposed anoxitropy, implying anoxic conditions beneath the wind-mixed surface layer, in Early Palaeozoic oceans could accommodate conditions involving high productivity (as implied by the rich acritarch record) and a fair preservation potential in the offshore 'black shale' facies (Berry et al., 1989).

\section{Large acanthomorphic acritarchs}

Rare specimens of large $(90-180 \mu \mathrm{m}$ in vesicle diameter) acanthomorphic acritarchs (Fig. 6a, c, d) occur in GGU samples 184002-184004 from the Buen Formation (Fig. 3). Generally, acritarchs average between 50 and $100 \mu \mathrm{m}$ (Tappan, 1980), although the normal range of Early Palaeozoic non-tasmanitid acritarchs is about 5$100 \mu \mathrm{m}$. By contrast, morphologically diagnostic large $(>100 \mu \mathrm{m})$ acanthomorphic acritarchs, although generally rare, appear widespread in Neoproterozoic sequences (Awramik et al., 1985; Butterfield et al., 1988; Jankauskas, 1979; Keller \& Jankauskas, 1980; Knoll \& Ohta, 1988; Knoll, 1984; Knoll \& Calder, 1983; Knoll et al., 1991; Pjatiletov \& Rudavskaya, 1985; Vidal, 1990; Yin, 1985; Zang, 1988; Zang \& Walter, 1989). In general (although often imprecisely expressed) the withinsample numbers of large acanthomorphs in late Proterozoic occurrences are low (Zang Wenlong, V. A. Rudavskaya, personal demonstration, 1990; M. Moczydlowska, G. Vidal \& V. A. Rudavskaya, unpublished data), often amounting to a few specimens in a normal palynological sample. This feature has a parallel in the notable rarity of large acanthomorphs in the present Early Cambrian material. Small or large, acanthomorphic acritarchs are generally rare in Late Proterozoic successions but the rarity of the large acanthomorphs must be considered as puzzling when compared with the vast numbers of accompanying 'normal size' (c. 5-70 $\mu \mathrm{m})$ typical Early Cambrian taxa.

Certain Proterozoic and Early Palaeozoic acritarchs (e.g. Tasmanites, Baltisphaeridium and Veryhachium) were compared to the phycoma stages of prasinophycean green algae (Jux, 1971; 1975) on the basis of their wall ultrastructure. Such studies have not been applied to Neoproterozoic and Early Cambrian acritarchs, although the incremental growth pattern of the prasinophycean phycomata from an initial size of about 10 $\mu \mathrm{m}$ to about $100-175 \mu \mathrm{m}$ at a mature stage (Tappan, 1980 ), as compared to the dimensions and growth patterns of some Neoproterozoic species of large acanthomorphs, are supposed to indicate possible prasinophycean affinity (Knoll et al., 1991; Vidal, 1990).

The large acanthomorphs from the Buen Formation (Fig. 6a, c, d) have processes and other morphological features that are present among typically Lower Cambrian smaller counterparts. Here, because they display distinctive morphologic attributes (apart from their larger dimensions), they are attributed to different taxa. Their presence in only three of the investigated samples that apparently do not differ from other processed samples is puzzling, but probably not more so than the presence or absence of 'normal' Cambrian-type taxa in the same samples (see Moczydłowska \& Vidal, 1992 for a discussion on related subjects). 


\begin{tabular}{|c|c|c|c|c|c|}
\hline & Biozones & \multicolumn{2}{|c|}{ (after Moczydłowska, 1989) } & \multicolumn{2}{|c|}{ Rock units } \\
\hline & Scandinavia & $\begin{array}{l}\text { USSR acritarch } \\
\text { 'horizons' }\end{array}$ & Poland Biozones & $\begin{array}{l}\text { Poland } \\
\text { Lublin slope }\end{array}$ & $\begin{array}{l}\text { S. Sweden } \\
\text { Ostergotland }\end{array}$ \\
\hline $\begin{array}{l}\dot{0} \\
\dot{\Sigma}\end{array}$ & $\begin{array}{l}\text { ECCAPARADOXIDES } \\
\text { OELANDICUS }\end{array}$ & Kibartai & E. OELANDICUS & Kostrzyn Fm & $\begin{array}{l}\text { OELANDICUS mudst } \\
\text { glauconite sst }\end{array}$ \\
\hline \multirow{4}{*}{$\frac{. \frac{5}{6}}{\frac{.}{6}}$} & PROAMPYX LINNARSSONI & 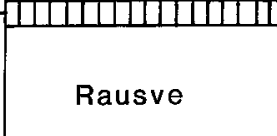 & PROTOLENUS & \multirow{3}{*}{$\begin{array}{c}\text { Radzyn \& } \\
\text { Kaplonosy Fms }\end{array}$} & Lingulid Sandstone \\
\hline & $\begin{array}{l}\text { HOLMIA KJERULFI grP } \\
\text { HOLMIA INUSITATA }\end{array}$ & 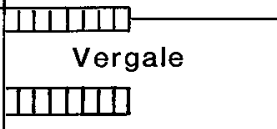 & HOLMIA & & $\begin{array}{l}\text { MICKWITZIA } \\
\text { Sandstone }\end{array}$ \\
\hline & $\begin{array}{l}\text { MOBERGELLA } \\
\text { SCHMIDTIELLUS } \\
\text { RUSOPHYCUS }\end{array}$ & 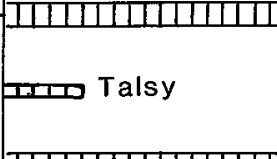 & SCHMIDTIELLUS & & \\
\hline & $\begin{array}{l}\text { PLATYSOLENITES } \\
\text { ANTIQUISSIMUS }\end{array}$ & Lontova & PLATYSOLENITES & Mazowsze Fm & \\
\hline \multirow{2}{*}{ ن } & \multirow{2}{*}{$\begin{array}{l}\text { SABELLIDITES } \\
\text { CAMBRIENSIS }\end{array}$} & Rovno & & Wrodowa Fm & \\
\hline & & एणIII- 'Kotlin' & $\begin{array}{l}\text { SABELLIDITES- } \\
\text { VENDOTAENIA }\end{array}$ & Lublin Fm & \\
\hline
\end{tabular}

\section{Biostratigraphy}

From previously reported macrofossil finds (Palmer \& Peel, 1979; Poulsen, 1974), the age of the Buen Formation can be conclusively established as late Early Cambrian (Bryant \& Pickerill, 1990). The acritarch assemblage recovered from the Buen Formation compares well with assemblages from Early Cambrian successions in the East European Platform, Baltoscandia (Eklund, 1990; Hagenfeldt, 1989; Moczydłowska, 1991; Moczydłowska \& Vidal, 1986; Vidal \& Nystuen, 1990b; Volkova et al., 1983), Scotland (Downie, 1982), Spain (Palacios \& Vidal, 1992; Gamez et al., in press); Svalbard (Knoll \& Sweet, 1987), central East Greenland (Downie, 1982; Moczydłowska \& Vidal, 1986) and Canada (Baudet et al., 1989; Figs 3-5).

No age diagnostic microfossils were recovered from samples from the lower arenaceous part of the Buen Formation. Investigated samples from the upper part of the Buen Formation are generally rich in phytoplankton, although some samples from the mudstone-dom- inated deep shelf portion are also poorly fossiliferous (particularly GGU samples 270591-270592; Figs 2, 3). In the light of the distribution of acritarchs in the above mentioned areas, most of the upper mud-dominated member thus appears to be of Vergale age (Heliosphaeridium dissimilare - Skiagia ciliosa acritarch zone; Moczydłowska, 1991). However, this assumption may imply stratigraphic extended ranges for three species (Tasmanites tenellus, Goniosphaeridium primarium, and perhaps Comasphaeridium mackenziana (as indicated in Fig. 4). In the case of the latter species the previously established range is poorly constrained.

The 3 specimens of $H$. notatum in GGU sample 274798 could perhaps suggest that a part of the investigated succession may as well be of Rausve age (equivalent to the Volkovia dentifera - Liepaina plana acritarch zone; Moczydłowska, 1991), although it could alternatively have an earlier appearance in the Buen Formation. 


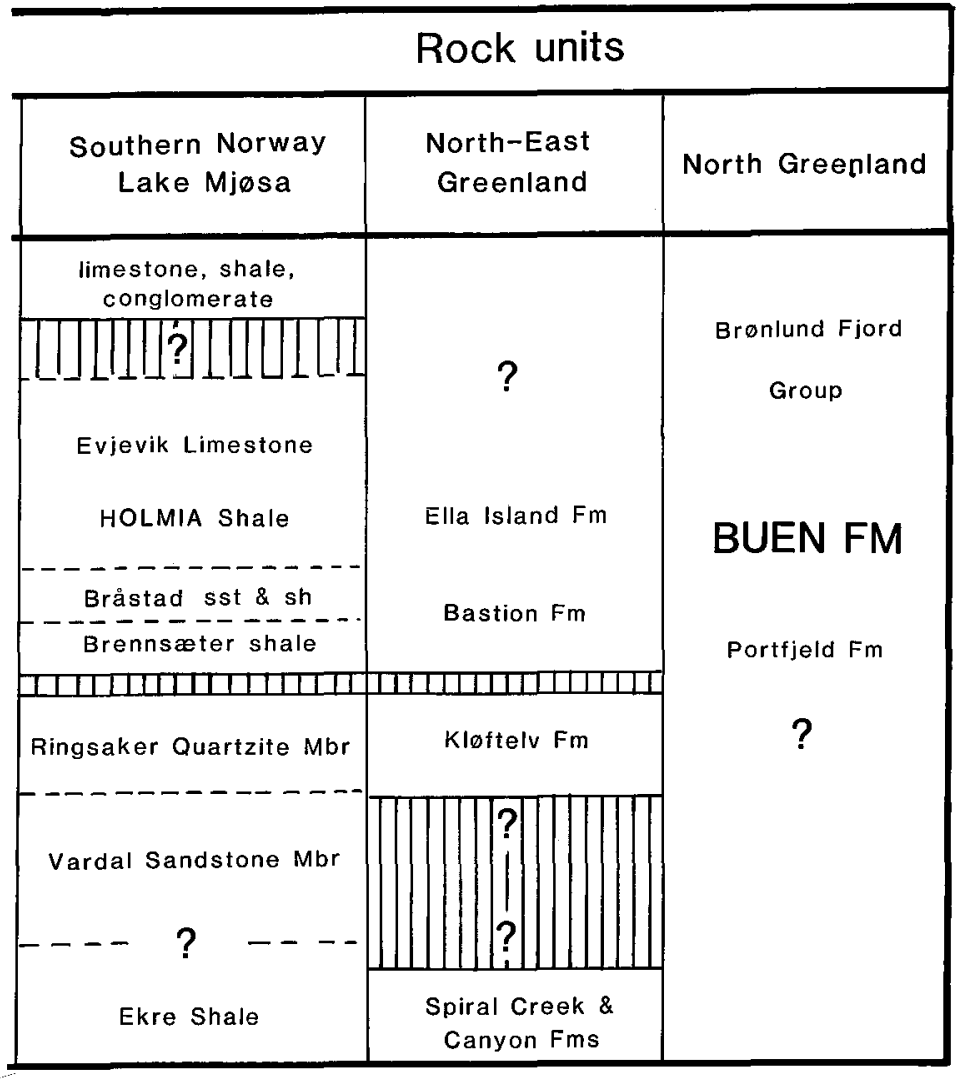

Fig. 5. Suggested biostratigraphic correlation of the Buen Formation in the context of Lower Cambrian biozonation for the East European Platform and Baltoscandia and suggested correlations of rock successions in North-East Greenland.

\section{Conclusions}

Acritarchs are extremely abundant and quite wellpreserved in deeper shelf mudstones (Figs 2,3) of the Buen Formation. Individual abundance and taxonomic diversity are substantially lower following a shallowing-up trend to alternating fine-grained sandstone and siltstone of inner shelf facies (Figs 2, 3). By contrast, GGU samples 274793-274794 from mudstones, interpreted as inner shelf storm beds (Figs 2, 3), are totally barren. This seems in agreement with previously observed trends of decreasing taxonomic diversity in littoral sequences as compared to contemporaneous deeper shelf settings.

High taxonomic diversity (as recorded in GGU samples 274570-274571, 274796-274800, 184002-184004) correlates positively with the presence of organic sapropel. This latter feature appears to be in agreement with suggested quiet water conditions and slow deposition resulting in the accumulation and preservation of abun- dant organic matter, perhaps under restricted circulation and dysaerobic conditions (see above).

Large-size (vesicle diameter $90-180 \mu \mathrm{m}$ ) acanthomorphic acritarchs occur in small numbers (GGU samples 184002-184004) in the deep shelf portion of the Buen Formation. These acanthomorphs are here described as two new species of the acritarch genus Comasphaeridium. As it is the case with large Neoproterozoic acanthomorphs, they are rare components among the small to normal size (vesicle diameter 5-70 $\mu \mathrm{m}$ ) characteristic Early Cambrian acritarch taxa in the Buen Formation.

By inference with the stratigraphic ranges of acritarchs elsewhere, the investigated upper mud-dominated member of the Buen Formation may be correlated with rocks of the Heliosphaeridium dissimilare Skiagia ciliosa acritarch zone (Vergale 'horizon') and perhaps the Volkovia dentifera - Liepaina plana acritarch zone (Rausve 'horizon'; Fig. 5). 


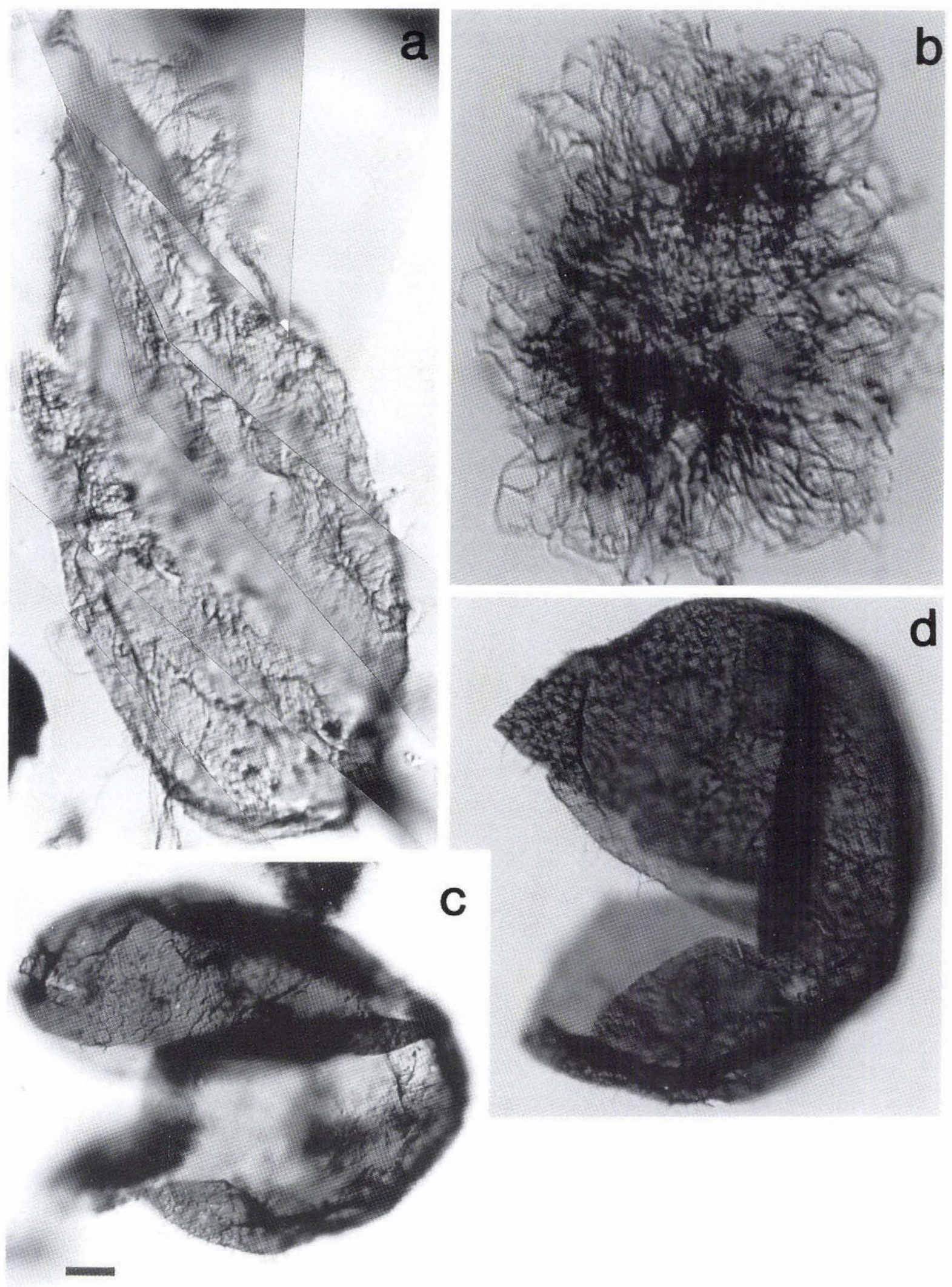




\section{Taxonomy}

The Buen Formation has yielded a rich and diverse acritarch assemblage including species of Archaeodiscina, Asteridium, Comasphaeridium, ?Celtiberium, $C y$ matiosphaera, Dictyotidium, Elektoriskos, Fimbriaglomerella, Globosphaeridium, Goniosphaeridium, Heliosphaeridium, Leiosphaeridia, Leiovalia, Lophosphaeridium, Multiplicisphaeridium, Pterospermella, Retisphaeridium, Skiagia and Tasmanites. These form genera comprise 52 form taxa, of which 9 are only identified at the form-genus level (Fig. 3).

The taxonomy of Early Cambrian acritarchs is based on gross morphological features and elements of ornamentation such as processes. Recent work on Early Cambrian acritarchs (e.g. Downie, 1982; Moczydłowska, 1988, 1991; Moczydłowska \& Vidal, 1988; Volkova et al., 1983) has resulted in a satisfactory state of taxonomic stability and understanding. Consequently, to avoid unnecessary repetition, in this paper we refrain from providing a complete taxonomic treatment of previously known taxa; these are only briefly described. More or less complete and recent synonymies, taxonomic information and geographic and stratigraphic distributions can be retrieved from papers by Downie (1982), Hagenfeldt (1989), Knoll \& Sweet (1987), Moczydłowska \& Vidal (1988), Moczydłowska (1988), Volkova $(1968,1981 \mathrm{a}, 1981 \mathrm{~b})$ and Volkova et al. (1983). The most recent and complete source of information can be found in Moczydłowska (1991).

Collection numbers prefixed by GGU refer to samples collected by the Geological Survey of Greenland. Figured specimens with numbers prefixed MGUH are kept in the Geological Museum, University of Copenhagen.

Dimensions are generally based on measurements of the best preserved material available and are given as the number of specimens $(N)$, mean $(\bar{x})$ for vesicle diameter and process length and $(\sigma)$ for standard deviation.

Fig. 6. Acritarchs from the Buen Formation, North Greenland. a, Comasphaeridium longispinosum n. sp., MGUH 21.516: H/46 from GGU sample 184004-B: 1, holotype. b, Comasphaeridium cf. strigosum (Jankauskas) Downie, 1982, MGUH 21.517: Y/35-4 from GGU sample 184003: 1. c, d, Comasphaeridium? densispinosum $\mathbf{n}$. sp., specimen at c, MGUH 21.518: E/36-4 from GGU sample 184002: 1; specimen at d, MGUH 21.519: Z/47-3 (below) from GGU sample 184003: 1 , holotype. Bar under c represents $10 \mu \mathrm{m}$ for a, $\mathrm{c} ; 4 \mu \mathrm{m}$ for $\mathrm{b}$ and 16 $\mu \mathrm{m}$ for $\mathrm{d}$.

\section{Archaeodiscina umbonulata Volkova, 1968}

Fig. 11e

This is represented by a single well-preserved specimen recovered from GGU sample 274796. Previous occurrences are given in Hagenfeldt (1989) and Moczydłowska \& Vidal (1986).

\section{Asteridium Moczydłowska 1991}

The genus Asteridium Moczydłowska, 1991 is represented in the Buen Formation by Asteridium lanatum (Volkova, 1969) Moczydłowska, 1991, A. (= Micrhystridium) ordensis (Downie, 1982) comb. nov. and $A$. tornatum (Volkova, 1968) Moczydłowska, 1991.

\section{Asteridium lanatum (Volkova, 1969) Moczydłowska, 1991}

Asteridium lanatum (Volkova, 1969) Moczydłowska, 1991 occurs in small numbers in several samples from the Buen Formation (Fig. 3). The dimensions of well preserved specimens indicate vesicle diameter $\bar{x}=10.8$ $\mu \mathrm{m}(N=8)$ and process length $\bar{x}=0.7 \mu \mathrm{m}(N=8)$. This taxon was selected by Moczydłowska (1991) as type species of the new form-genus Asteridium, thus transferring several species previously attributed to the formgenus Micrhystridium (Deflandre, 1937) Sarjeant, 1967 to the new form-genus. Previous occurrences were recently listed by Hagenfeldt (1989) and Moczydłowska (1991).

Asteridium ordensis (Downie, 1982), comb. nov.

Fig. 9b

1982 Micrhystridium ordensis sp. nov. Downie, p. 262, figs $6 \mathrm{ff}-\mathrm{hh}, 7 \mathrm{a}$

Material. Four well-preserved specimens.

Emended diagnosis. Organic-walled spheroidal vesicle with numerous medium length, straight, thin processes of equal width with blunt distal ends. 

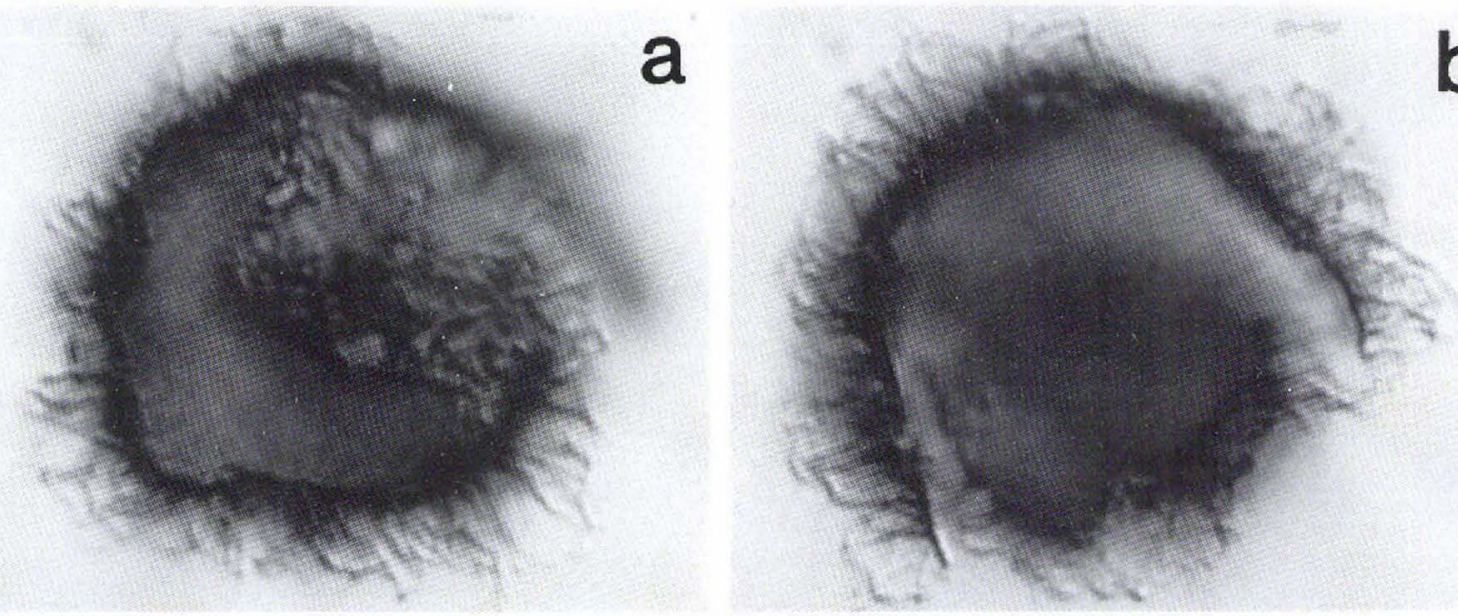

\section{b}

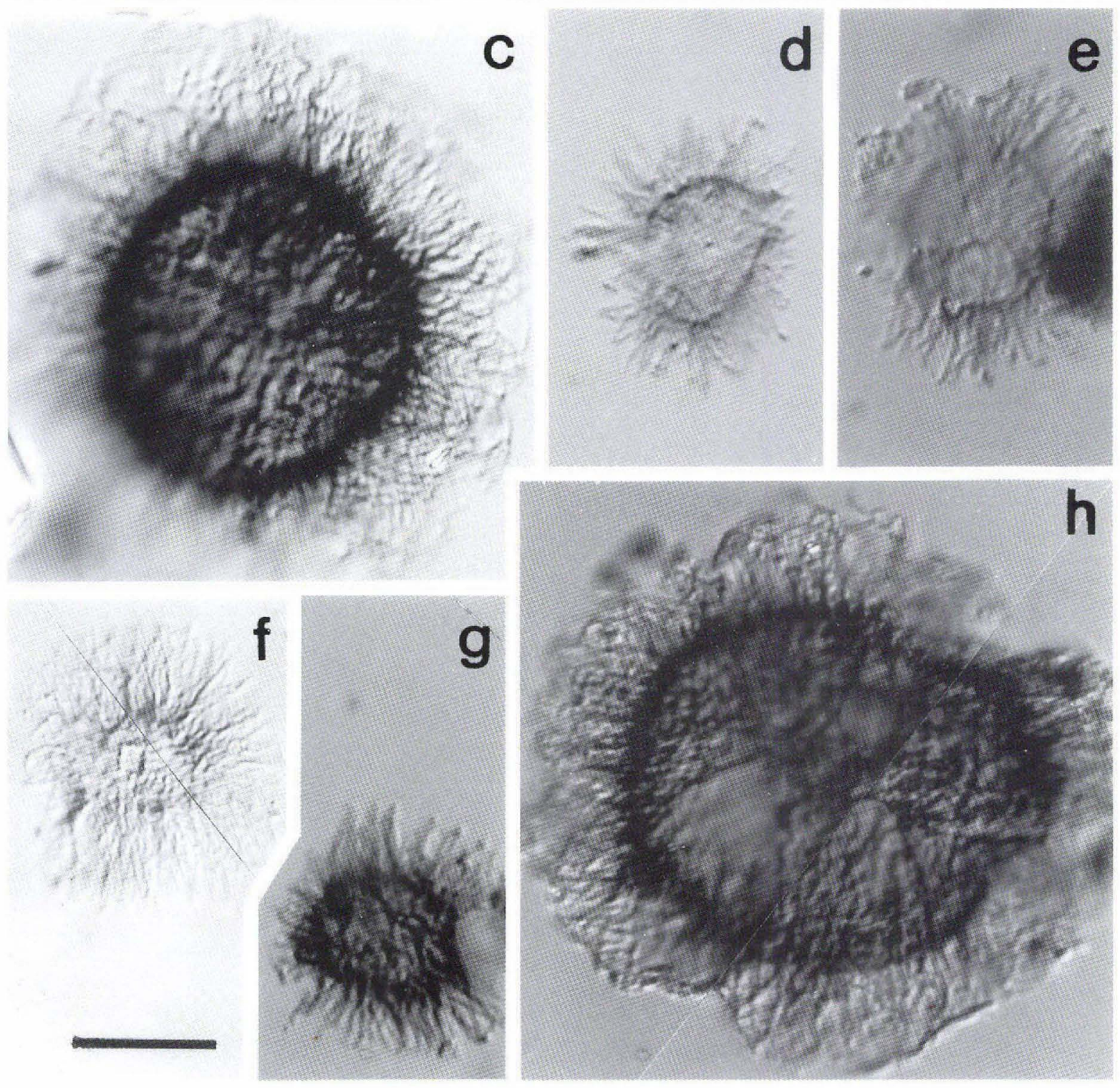


Remarks. The morphotype attributed by Downie (1982) to Micrhystridium ordensis displays morphological attributes established to the form-genus Asteridium Moczydlowska, 1991. A. ordensis differs from other species of the genus by its straight, widely-spaced and more robust processes, with blunt distal ends.

Dimensions. Vesicle diameter $7-8 \mu \mathrm{m}$, process length $1.5-4 \mu \mathrm{m}$.

Occurrence and stratigraphic range. Lower Cambrian Buen Formation of North Greenland (Figs 3, 4). Lower Cambrian Fucoid Beds in Scotland, Bastion Formation in North-East Greenland, Gog Formation and Mt. Whyte Formation in Alberta, Canada.

\section{Asteridium tornatum (Volkova, 1968) Moczydłowska, 1991}

Fig. 9a

Asteridium tornatum (Volkova, 1968) Moczydłowska, 1991 is rare in the investigated samples from the Buen Formation (Fig. 3). It consists of organic-walled circular to oval vesicles $8-21 \mu \mathrm{m}$ in diameter covered by evenly distributed short, thorn-like processes $1-2 \mu \mathrm{m}$ in length. Previous occurrences were listed by Volkova (1969a, b), Volkova et al. (1979) and Moczydłowska (1991).

Fig. 7. Acritarchs from the Buen Formation, North Greenland. a-b, Comasphaeridium molliculum Moczydłowska \& Vidal, 1988, two focal levels, MGUH 21.520: K/46-4 from GGU sample 274795: A1. c, h, Comasphaeridium cf. strigosum (Jankauskas) Downie, 1982, specimen at c, MGUH 21.521: U/41-3 from GGU sample 274797: G1; specimen at h, MGUH 21.526: U/50-3 from GGU sample 274571: G2. d, e Comasphaeridium mackenziana Baudet, Aitken \& Vanguestaine, 1989, specimen at d, MGUH 21.522: S/47 from GGU sample 274796: G1; specimen at e, MGUH 21.523: K/27 from GGU sample 274571: G2. f, Comasphaeridium sp., MGUH 21.524: D/43 from GGU sample 274799: A1. g, Comasphaeridium strigosum (Jankauskas) Downie, 1982, MGUH 21.525: Z/32 (below) from GGU sample 184003: 1. Bar under f represents $10 \mu \mathrm{m}$.

\section{?Celtiberium geminum Fombella, 1977}

Fig. 8d, e

A single acritarch specimen from GGU sample 274799 is attributed to ?Celtiberium geminum Fombella, 1977. It has a spherical central vesicle $(6 \mu \mathrm{m}$ in diameter) whose cavity seems to be in communication with tapering conical processes $(2-2.5 \mu \mathrm{m}$ in length) with rounded apical ends. C. geminum is formerly known from Middle Cambrian rocks in northern Spain (Fombella, 1977) and was recently reported by Eklund (1990) from the lower Middle Cambrian glauconite sandstone unit in Östergötland, southern Sweden.

\section{Comasphaeridium sp. A Downie, 1982} Fig. 8j

1982 Comasphaeridium sp. A. Downie, p. 260, fig. $6 \mathrm{~m}$ 1989 Comasphaeridium sp. A in Downie, 1982 Baudet, Aitken \& Vanguestaine, p. 140, pl. 1, figs 18-19.

Material. Eight well-preserved specimens.

Description. Organic-walled sphaeroidal vesicle with numerous clearly defined processes tightly arranged and tapering towards the sharp tips.

Remarks. This species of Comasphaeridium differs form C. velvetum Moczydlowska, 1988 and C. agglutinatum Moczydłowska, 1988 by having free-standing and unpasted, longer and tapering, sharp pointed processes. It also differs from Comasphaeridium strigosum (Jankauskas) Downie, 1982 through its clearly defined, not pasted and longer processes, and by the clearly delimited outline of the vesicle.

Dimensions. Vesicle diameter: $N=6, \bar{x}=8.6 \mu \mathrm{m}$, processes: $N=6, \bar{x}=5.5 \mu \mathrm{m}$.

Occurrence and stratigraphic range. Lower Cambrian Buen Formation of North Greenland (Figs 3, 4). Lower Cambrian Fucoid Beds in Scotland, Holmia Shales in southern Norway and Gog Formation in Alberta, Canada (Downie, 1982); upper part of Lower Cambrian Vampire Formation and Sekwi Formation in northwestern Canada (Baudet et al., 1989).

Acritarchs clearly belonging to the genus Comasphaeridium, but not being clearly attributable to any known form species of this genus, are here referred to $\mathrm{Co}$ masphaeridium spp. in Fig. 3. 

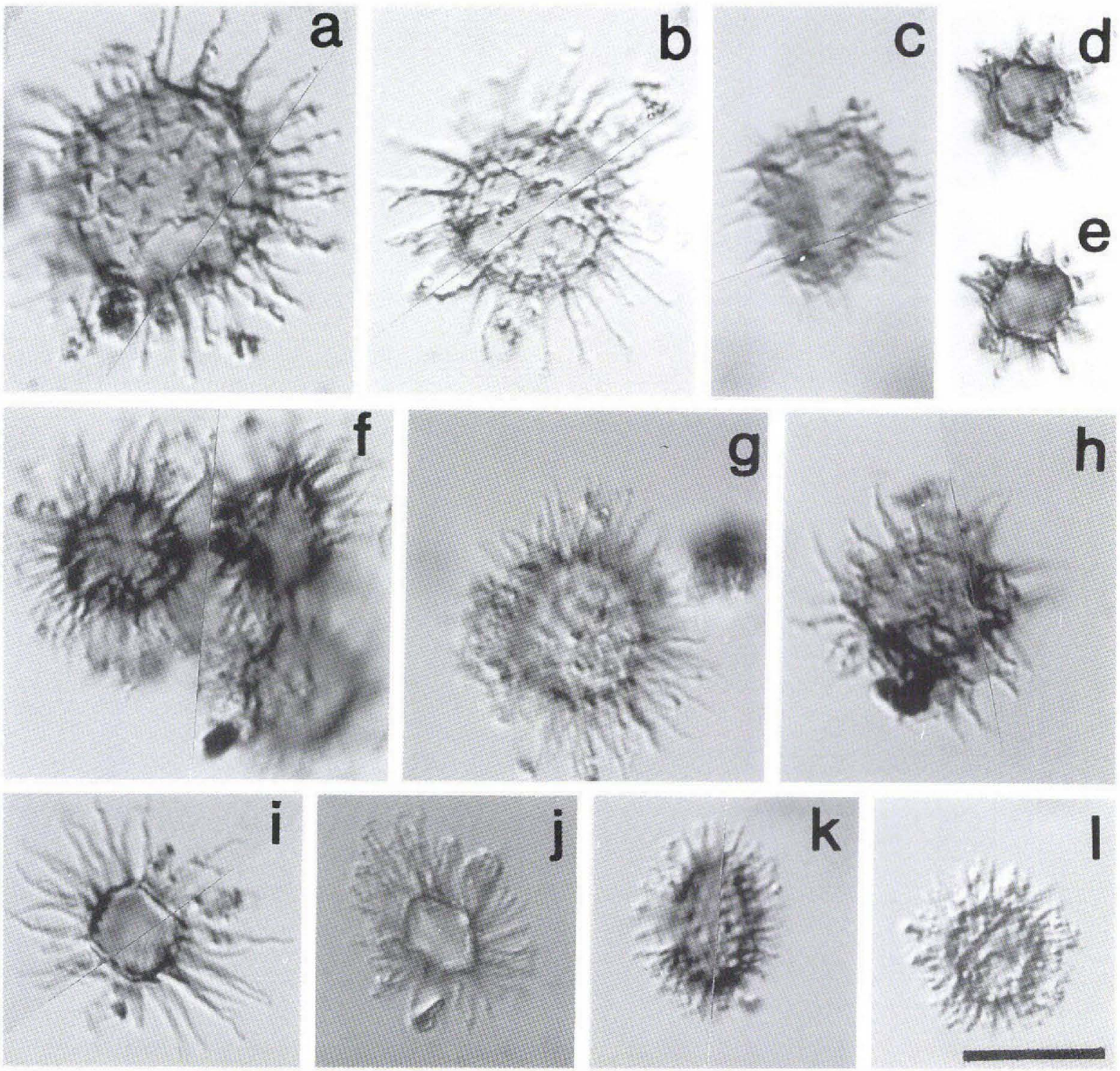

Fig. 8. Acritarchs from the Buen Formation, North Greenland. a, b, Heliosphaeridium lubomlense (Kirjanov, 1974) Moczydłowska, 1991, MGUH 21.527: W/30-4 and MGUH 21.528: R/43-1/3 from GGU sample 274797: G1. c, Heliosphaeridium obscurum (Volkova, 1969) Moczydłowska, 1991, MGUH 21.529: N/42-3 from GGU sample 184002: 1. d, e, ?Celtiberium geminum Fombella, 1977 at two focal levels, MGUH 21.530: K/26 from GGU sample 274799: A1. f, clustered specimens of Comasphaeridium mackenziana Baudet, Aitken \& Vanguestaine, 1989, MGUH 21.531: T/48 4 from GGU sample 184002: 1. g. k, Heliosphaeridium coniferum (Downie, 1982) Moczydłowska, 1991, specimen at g, MGUH 21.532: R/45-3 from GGU sample 274796: G1; specimen at k; MGUH 21.533: R/45-3 from GGU sample 274796: G1. h, Goniosphaeridium volkovae Hagenfeldt, 1989. MGUH 21.534: Z/48-3 (below) from GGU sample 184002: 1. i, Goniosphaeridium sp. A, MGUH 21.535: Z/49-3 (below) from GGU sample 274796: G1. j. Comasphaeridium sp. A Downie, 1982, MGUH 21.536: E/40 from GGU sample 274796: G1. I. Comasphaeridium agglutinatum Moczydlowska, 1988, MGUH 21.537: Z/43-2 from GGU sample 274571: G2. Bar under 1 represents $13 \mu \mathrm{m}$ for a $10 \mu \mathrm{m}$ for b-l. 
Comasphaeridium agglutinatum Moczydłowska, 1988

Fig. 81

Two specimens recovered from GGU sample 274571 (Fig. 3) are attributed to Comasphaeridium agglutinatum. They consist of a spheroidal vesicle ranging $6-8 \mu \mathrm{m}$ in diameter and surrounded by densely arranged agglutinated processes. The species is previously known only from the lower part of the Whodawa Formation and the Mazowsze Formation in Poland (Moczydlowska, 1991).

\section{Comasphaeridium mackenziana Baudet, Aitken \& Vanguestaine, 1989 \\ Fig. 7d, e}

1989 Comasphaeridium mackenziana n. sp. Baudet, Aitken \& Vanguestaine, p. 138-140, pl. 1, figs 14-17.

Material. Thirteen well-preserved specimens; abundant in GGU sample 184002 from the Buen Formation (Figs $3,4)$.

Description. Small acritarchs consisting of a central spherical vesicle having a smooth outer surface covered by numerous, well-defined, closely arranged, filiform and flexible processes of equal thickness.

Dimensions. Vesicle diameter: $N=12, \bar{x}=8.08 \mu \mathrm{m}$, processes: $N=12, \bar{x}=3.08 \mu \mathrm{m}$.

Occurrence and stratigraphic range. Lower Cambrian Buen Formation, (Figs 3-4), North Greenland. Previous occurrences are $14 \mathrm{~m}$ above the lower junction of the Lower Cambrian Sekwi Formation and 2 and $8 \mathrm{~m}$ below the upper junction of the Vampire Formation in the central Mackenzie Mountains, north-western Canada (Baudet et al., 1989).

\section{Comasphaeridium molliculum Moczydłowska \& Vidal, 1988}

Fig. $7 \mathrm{a}, \mathrm{b}$

For synonyms see Moczydłowska \& Vidal (1988) and Hagenfeldt (1989). Acritarchs consisting of a central spherical vesicle (vesicle diameter: $N=6,65-70 \mu \mathrm{m}$ ) with smooth outer surface covered by numerous, closely arranged filiform and flexible processes (process length: 5-7 $\mu \mathrm{m}$ ). Excystment (not seen in the present material) by median split (Moczydłowska \& Vidal, 1988). Previ- ous occurrences were listed by Moczydłowska \& Vidal (1988), Hagenfeldt (1989) and Vidal \& Nystuen (1990b).

\section{Comasphaeridium? densispinosum Vidal}

n. $\mathrm{sp}$.

Fig. 6c, d

Derivation of name. Latin densum, dense, and spina, spine; relating to the densely arranged crown of processes covering the vesicle.

Material. Eight well-preserved specimens.

Diagnosis. An acritarch species with spheroidal vesicle densely covered with short, minute, simple ciliar-like processes. The processes are generally simple, but may in some instances display a distinct, low, conical, proximal attachment to which a ciliar-like portion of the process is attached. Excystment by median split.

Description. The generic assignation of this taxon is uncertain, being attributed with certain reservations to Comasphaeridium? This is because most specimens display process dimorphism, possessing abundant ciliarlike short processes together with few processes that display a conical-shaped basal attachment, a feature absent among species of Comasphaeridium.

Dimensions. Vesicle diameter: $N=8, \bar{x}=94.1 \mu \mathrm{m}, \sigma=$ $36.9 \mu \mathrm{m}$. Process length: $\bar{x}=1 \mu \mathrm{m}$. Width of process attachment $\bar{x}=1 \mu \mathrm{m}$, height of process attachment $\bar{x}=$ $1 \mu \mathrm{m}$.

Occurrence and stratigraphic range. Lower Cambrian Buen Formation in North Greenland (Figs 3-4).

\section{Comasphaeridium longispinosum Vidal}

n. sp.

Fig. 6a

Derivation of name. Latin longum, long and spina, spine; relating to the extremely long processes covering the vesicle.

Material. A single specimen from GGU sample 184004-B.

Description. Acritarch with large spheroidal to ovoidal vesicle covered by densely interwoven and, in relation to the vesicle diameter, long, slender and very thin processes. 

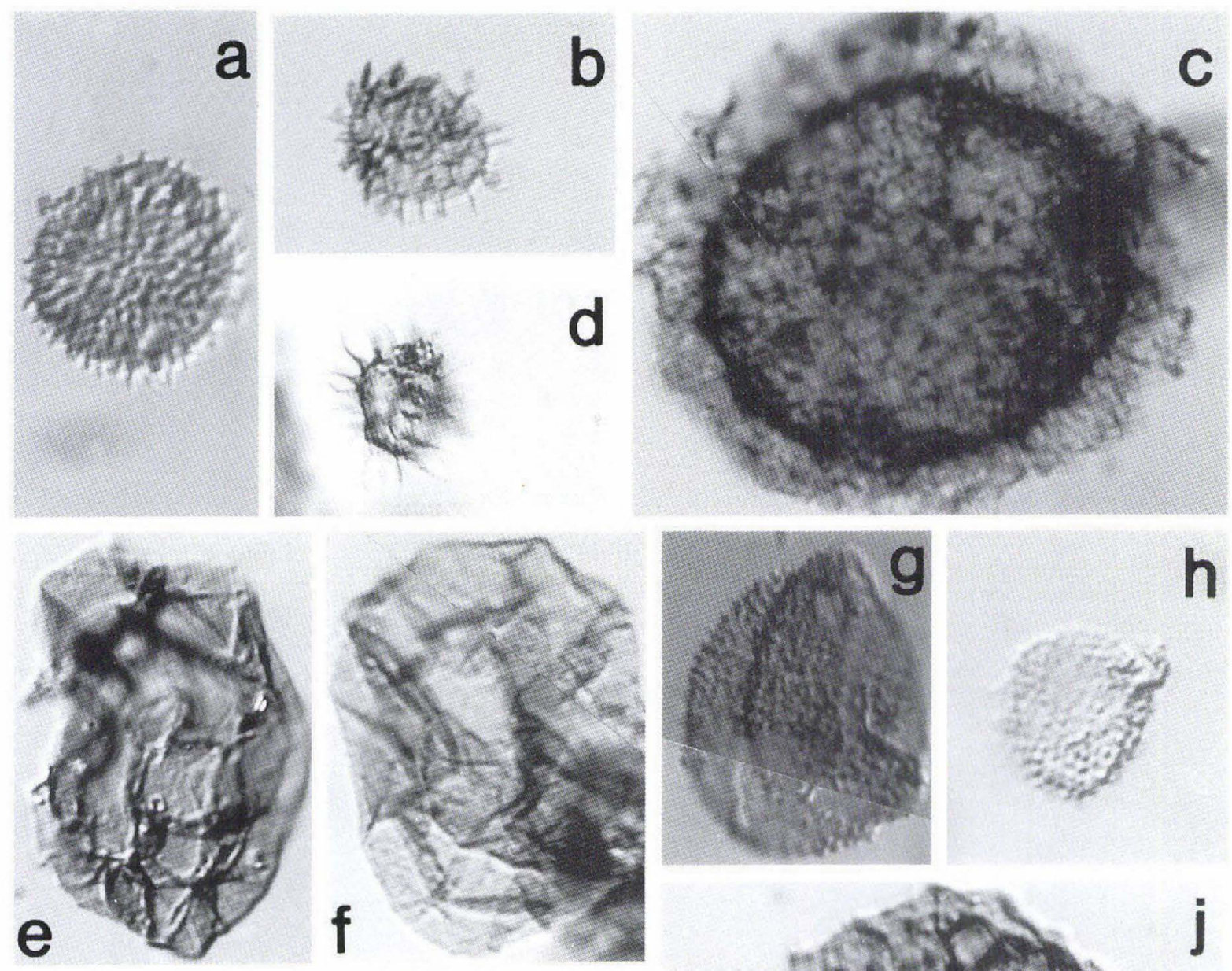

h
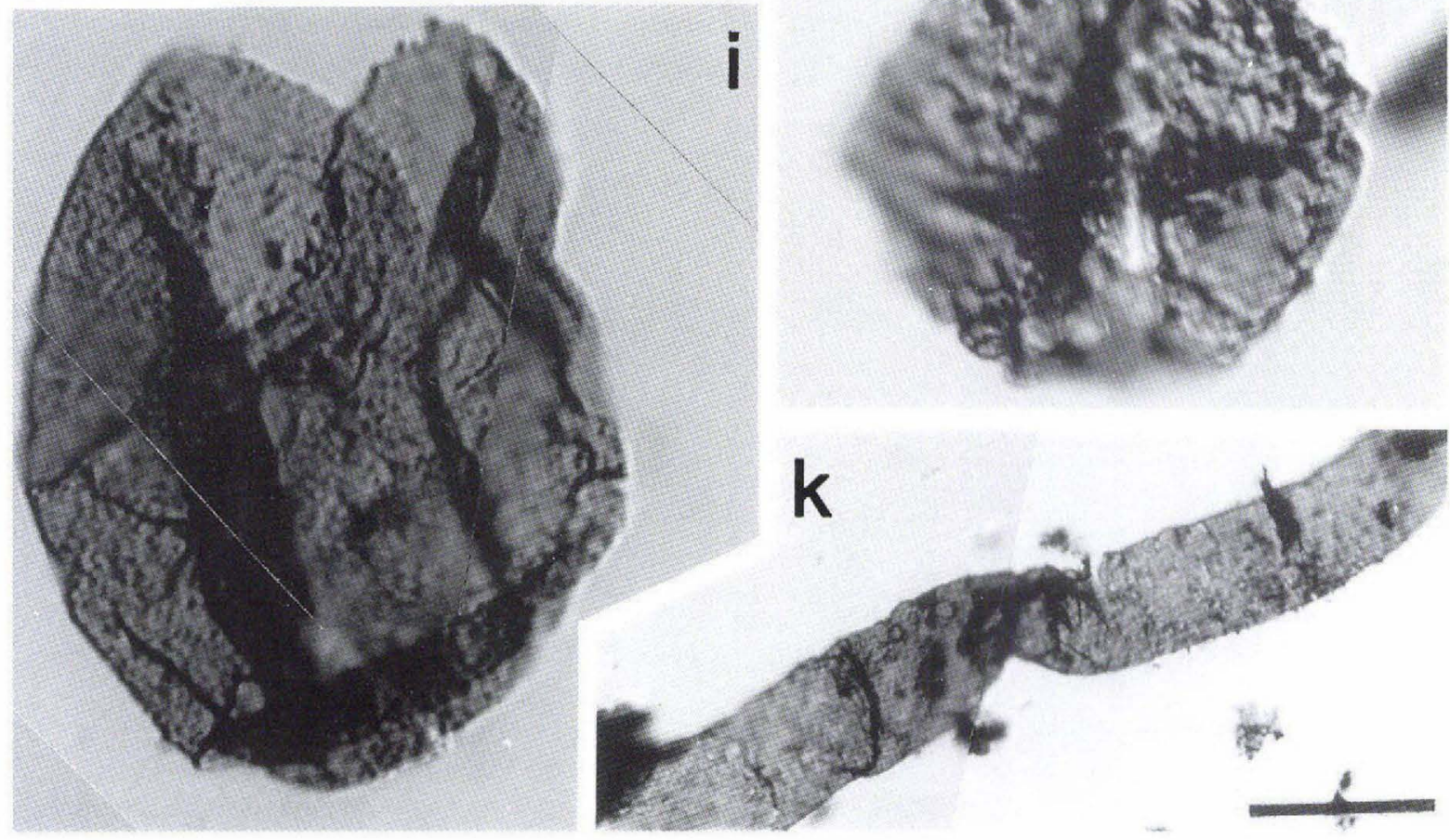
Dimensions. The single recovered specimen has a vesicle diameter of $\bar{x}=180 \mu \mathrm{m}$, whereas the sub-micron wide processes are $\bar{x}=20 \mu \mathrm{m}$ in length.

Occurrence and stratigraphic range. Lower Cambrian Buen Formation in North Greenland (Figs 3, 4).

\section{Comasphaeridium strigosum (Jankauskas) Downie, 1982}

Fig. $7 \mathrm{~g}$

Acritarchs attributed to $C$. strigosum are rare, but occur through most of the sampled succession of the Buen Formation. The vesicle diameters range from $18-22 \mu \mathrm{m}$, whereas the length of processes is $3-6 \mu \mathrm{m}$. For synonymies and previous occurrences see Hagenfeldt (1989) and Moczydłowska (1991).

\section{Comasphaeridium cf. strigosum (Jankauskas) Downie, 1982 \\ Figs $6 \mathrm{~b}, 7 \mathrm{c}, \mathrm{h}$}

Acritarchs attributed to this species consist of a central spherical vesicle (diameter $\bar{x}=20.3 \mu \mathrm{m}, \sigma=5.0$ $\mu \mathrm{m}, N=13$ ) surrounded by densely arranged simple processes (process length $\bar{x}=6.1 \mu \mathrm{m}, \sigma=2.2 \mu \mathrm{m}, N=$ 13).

Fig. 9. Acritarchs from the Buen Formation, North Greenland. a, Asteridium tornatum (Volkova, 1968) Moczydlowska, 1991, MGUH 21.538: C/42 from GGU sample 274571: G2. b, Asteridium (= Micrhystridium) ordensis (Downie, 1982) comb. nov., MGUH 21.539: V/45-2 from GGU sample 184002: 1. c, Heliosphaeridium dissimilare (Volkova, 1969) Moczydłowska, 1991, MGUH 21.540: R/45-2 from GGU sample 274799: A1. d, Pterospermella sp., MGUH 21.541: S/43 from GGU sample 184004: A1. e, Retisphaeridium dichamerum Staplin, Jansonius \& Pocock, 1965, MGUH 21.542: B/43-4 from GGU sample 274798: A1. f, Retisphaeridium dichamerum Staplin, Jansonius \& Pocock, 1965, MGUH 21.543: L/49 from GGU sample 274796: G1. g, Lophosphaeridium dubium (Volkova, 1968) Moczydłowska, 1991, MGUH 21.544: K/43-4 from GGU sample 274571: G2. h, Lophosphaeridium tentativum Volkova, 1968, MGUH 21.545: J/26-4 from GGU sample 274573B: G1. i, Lophosphaeridium sp., MGUH 21.546: V/32-4 from GGU sample 184003: 1. j, Lophosphaeridium truncatum Volkova, 1969, MGUH 21.547: N/27-4 from GGU sample 274796: G1. k, Cyanobacterial sheath, MGUH 21.548: Z/28 from GGU sample 184002: 1. Bar under $\mathrm{k}$ represents $10 \mu \mathrm{m}$ for $\mathrm{a}-\mathrm{j}$ and $15.5 \mu \mathrm{m}$ for $\mathrm{k}$.

\section{Cymatiosphaera postii (Jankauskas,} 1976) Jankauskas, 1979

Only 2 specimens of $C$. postii were recovered (Fig. 3). Overall dimensions range from $20-25 \mu \mathrm{m}$ whereas the diameter of the inner body is $16 \mu \mathrm{m}$. Synonymy and previous occurrences in Lower Cambrian strata were listed by Hagenfeldt (1989) and Moczydłowska (1991).

\section{Cymatiosphaera sp.}

Fig. $10 \mathrm{c}, \mathrm{d}$

Acritarchs here attributed to Cymatiosphaera sp. (sensu Volkova et al., 1979) are very rare and restricted to 4 samples (Fig. 3). They are comparable to forms from the Vergale 'horizon' in Latvia illustrated by Volkova et al. (1979, pl. 15, figs 1-2) under the name Cymatiosphaera div. sp. Four specimens recovered have a mean vesicle diameter of $33 \mu \mathrm{m}$.

\section{Dictyotidium Eisenack, 1955 emend. Staplin, 1961}

Type species. Leiosphaera (= Dictyotidium) dictyotum Eisenack, 1938, p. 27-28, pl. 3; figs 8a-c.

\section{Dictyotidium perforatum Vidal n. sp. Fig. 10a}

Derivation of name. Latin perforatum, perforated; relating to the perforations observed on the fields limited by the reticular ornamentation of the vesicle.

Material. Three specimens from GGU samples 274799 and 274800.

Diagnosis. Spheroidal vesicle with reticular surface sculpture. The areas limited by reticula have clearly defined circular pores.

Dimensions. The overall dimensions are derived from the measurement of 3 deformed specimens and suggest a diameter of $>60->80 \mu \mathrm{m}$. The lumina of the reticular sculpture are $\bar{x}=1-2 \mu \mathrm{m}$ wide. Diameter of pores $<1$ $\mu \mathrm{m}$.

Remarks. The actual microfossils display a strong overall similarity with $D$. priscum Kirjanov \& Volkova, 1979 (Fig. 10b). Specimens attributable to the latter species 

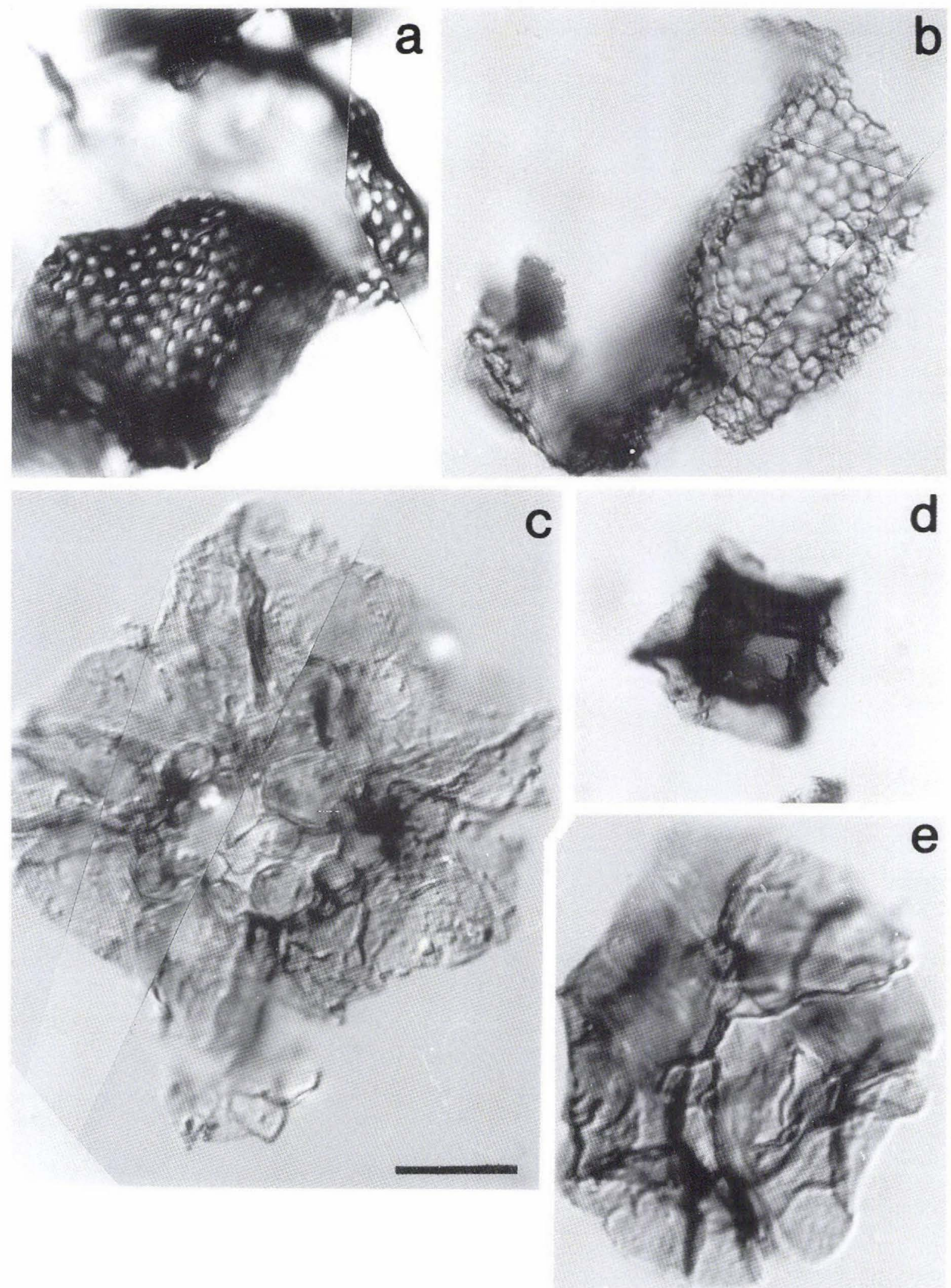
occur in GGU sample 274800. Despite comparable dimensions, they differ from the present taxon by the obvious lack of well-defined pores and the much lower relief of the reticular sculpture. An additional species of Dictyotidium (D. birvetense Paškevičiene, 1979) has smaller overall dimensions $(26-45 \mu \mathrm{m})$ and possesses a reticular sculpture defining much larger $(5-9 \mu \mathrm{m})$ and apparently less regular fields.

Occurrence and stratigraphic range. Lower Cambrian Buen Formation of North Greenland (Figs 3, 4).

\section{Elektoriskos sp. A}

Fig. 13b

This species of Elektoriskos Loeblich, 1970 is represented by a single distinctive specimen in GGU sample 184002 (Fig. 3). It consists of a small $(4.5 \mu \mathrm{m}$ in diameter) spherical vesicle densely covered with slender, meandering processes $5 \mu \mathrm{m}$ in length that stand on slightly inflated proximal attachments. The specimen differs substantially from other species of small acritarchs such as Heliosphaeridium and Asteridium by the character of the processes and their proximal attachments.

\section{Fimbriaglomerella Loeblich \& Drugg, 1968}

Fig. $14 \mathrm{e}, \mathrm{f}$

This genus is represented by two species, Fimbriaglomerella membranacea (Kirjanov, 1974) Moczydłowska \& Vidal, 1988 (Fig. 14e) and F. minuta (Jankauskas, 1979) Moczydłowska \& Vidal, 1988 (Fig. 14f), both of which are represented by single well-preserved specimens in GGU sample 274796. Contrary to specimens reported by Moczydlowska \& Vidal (1988), the present specimens are flattened by sediment compaction.

Fig. 10. Acritarchs from the Buen Formation, North Greenland. a, Dictyotidium perforatum Vidal n. sp., MGUH 21.549: F/37 from GGU sample 274799: A1, holotype. b, Dictyotidium priscum Kirjanov \& Volkova, 1979, MGUH 21.550: J/50-3 from GGU sample 274800: A1. c-e, Cymatiosphaera sp., specimen at c, MGUH 21.551: R/43-1 from GGU sample 274796: G1; specimen at d, MGUH 21.552: E/38-1 from GGU sample 274795: A1; specimen at e, MGUH 21.553: O/50-2 from GGU sample 274800: A-1. Bar under c represents $10 \mu \mathrm{m}$ for a, c, e; $15.5 \mu \mathrm{m}$ for $\mathrm{b} ; 25 \mu \mathrm{m}$ for $\mathrm{d}$.

\section{Globosphaeridium cerinum (Volkova) Moczydłowska, 1991}

Fig. 13c

This is present in GGU samples 274570 and 274796. The vesicle diameter and process length of 4 recovered specimens ranges $32-35 \mu \mathrm{m}$ and $5 \mu \mathrm{m}$, respectively.

Moczydlowska (1991) transferred acritarchs attributed to Baltisphaeridium cerinum Volkova, 1968 and Electoriskos cerinus (Volkova) Vanguestaine, 1968 to the new genus Globosphaeridium. Previous occurrences and synonymy were listed by Hagenfeldt (1989).

\section{Goniosphaeridium primarium (Jankauskas) Downie, 1982} Fig. 11a

Microfossils here attributed to the acritarch genus Goniosphaeridium Eisenack, 1969 emend. Kjellström, 1971 are here referred to G. primarium (Jankauskas) Downie, 1982 recorded as 2 specimens (vesicle diameter 28-48 $\mu \mathrm{m}$, process length $20-30 \mu \mathrm{m}$, width of process base 7-9 $\mu \mathrm{m}$ ) in GGU sample 274796. Previous occurrences were listed by Volkova et al. (1979) and additional occurrences in the Lower Cambrian of Baltoscandia were reported by Vidal \& Nystuen (1991b).

One specimen uncertainly identified as Goniosphaeridium sp. was also recovered from GGU sample 274571.

\section{Goniosphaeridium sp. A}

Fig. 8i

Rare acritarchs uncertainly attributed to genus $G o$ niosphaeridium are here referred to Goniosphaeridium sp. A. The conical nature of the compressed processes is evident and may suggest original connection between processes and the inner vesicle cavity. However, this feature cannot be ascertained in the specimens available.

\section{Goniosphaeridium varium (Volkova, 1969) Downie, 1982}

This is represented by a single poorly preserved specimen about $44 \mu \mathrm{m}$ in diameter (Fig. 3, GGU sample 184003). 

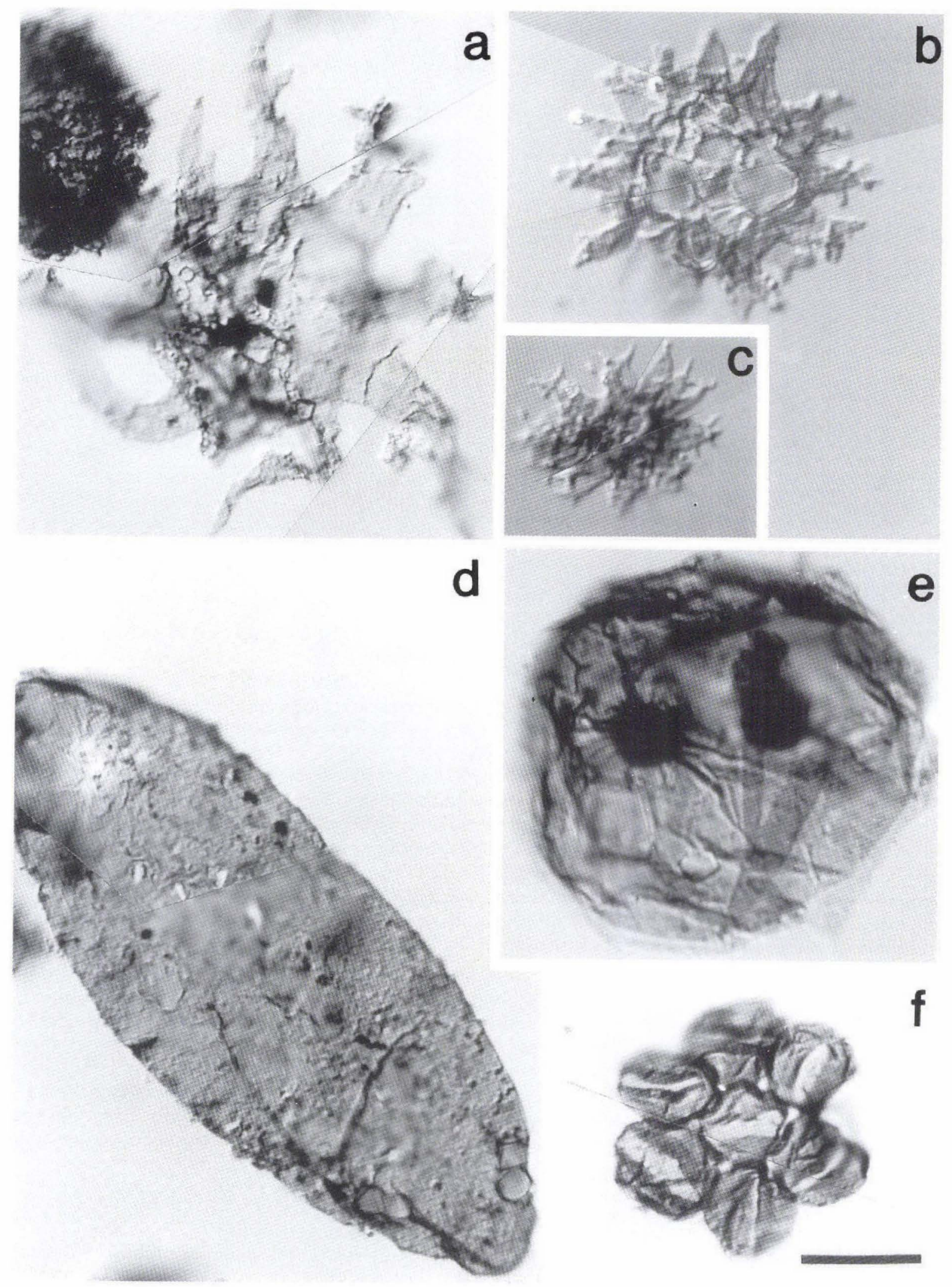


\section{Goniosphaeridium volkovae Hagenfeldt, 1989}

Fig. 8h

Acritarchs here attributed to Goniosphaeridium volkovae Hagenfeldt, 1989 (Hagenfeldt, 1989, pl. 3; fig 1) consist of 20 variably preserved specimens in GGU sample 184002 . They consistently possess a central ovoidal to spherical vesicle tightly covered by discrete conical, sharp-pointed, processes, apparently in communication with the inner cavity of the vesicle. The maximal vesicle diameter ranges from $7-8 \mu \mathrm{m},(\bar{x}=7.2 \mu \mathrm{m})$, and the length of processes ranges from $1.5-4 \mu \mathrm{m}(\bar{x}=2.8$ $\mu \mathrm{m})$.

Hagenfeldt (1989) listed occurrences in the USSR and in Scandinavia, where the species occurs in beds attributed to the Lower Cambrian Vergale and Rausve 'horizons', the lower Middle Cambrian Kibartai 'horizon' and Eccaparadoxides oelandicus Zone.

\section{Granomarginata squamacea Volkova, 1968}

A few specimens placed here show a central vesicle diameter of $20 \mu \mathrm{m}$ and outer wing diameter ranging $30-40 \mu \mathrm{m}$. Synonymies and previous occurrences were mentioned by Hagenfeldt (1989) and Moczydłowska (1991).

\section{Heliosphaeridium sp.}

Acritarchs identified as Heliosphaeridium sp. occur in two samples (Fig. 3); they are small forms which can not be identified at the specific level.

Fig. 11. Acritarchs from the Buen Formation, North Greenland. a, Goniosphaeridium primarium (Jankauskas) Downie, 1982, MGUH 21.554: Z/36-3 from GGU sample 274796: G1. b, c, Multiplicisphaeridium dendroideum (Jankauskas, 1976) Jankauskas \& Kirjanov, 1979, specimen at b, MGUH 21.555: Z/36 from GGU sample 274796: G1; specimen at c, MGUH 21.556: X/39-1 from GGU sample 274796: G1. d, Leiovalia tenera Kirjanov, 1974, MGUH 21.557: H/37-4 from GGU sample 184002: 1. e, Archaeodiscina umbonulata Volkova, 1968, MGUH 21.558: Z/29 from GGU sample 274796: G1. f, Leiosphaeridia sp., MGUH 21.559: O/25 from GGU sample 274799: A1. Bar under $\mathrm{f}$ represents $15.5 \mu \mathrm{m}$ for $\mathrm{a}, \mathrm{d} ; 10 \mu \mathrm{m}$ for b-c, e-f.
Heliosphaeridium coniferum (Downie, 1982) Moczydłowska, 1991

Fig. $8 \mathrm{~g}, \mathrm{k}$

Heliosphaeridium coniferum (vesicle diameter 5-9 $\mu \mathrm{m}$, process length $<2-2 \mu \mathrm{m}$ ) was recently emended by Moczydlowska (1991) who provided a list of previous citations. The species is present in small numbers in GGU sample 184002 and more abundantly in GGU sample 274496. Specimens from the Buen Formation closely correspond to specimens from eastern Poland illustrated by Moczydłowska (1991), whereas they seem quite different from specimens from the lower part of the 'Fucoid' Beds in Scotland illustrated by Downie (1982).

\section{Heliosphaeridium dissimilare (Volkova, 1969) Moczydłowska, 1991}

Fig. 9c

The species (vesicle diameter 7-10 $\mu \mathrm{m}, \bar{x}=10.7 \mu \mathrm{m}$, $\sigma=3.2, N=36$; process length $2-4 \mu \mathrm{m}, \bar{x}=3.6 \mu \mathrm{m}, \sigma$ $=1.03, N=58$ ) was also emended by Moczydłowska (1991), who listed previous occurrences (see also Vidal \& Nystuen, 1990b).

\section{Heliosphaeridium lubomlense (Kirjanov, 1974) Moczydłowska, 1991}

Fig. 8a, b

Heliosphaeridium lubomlense consists of acritarchs with a distinctive spherical vesicle $12-15 \mu \mathrm{m}$ in diameter, with irregular circular outline and possessing numerous straight and equally distributed processes. The processes (5-7 $\mu \mathrm{m}$ in length) have conical proximal portions tapering in the central part and are slightly widened at the distal portion.

\section{Heliosphaeridium notatum (Volkova, 1969) Moczydłowska, 1991}

This species is extremely rare in the present material, being only represented by 3 specimens unsuitable for illustration (vesicle diameter $22-24 \mu \mathrm{m}$; process length $>2-3 \mu \mathrm{m}$ ) in GGU sample 274798. Synonymy and previous occurrences were listed by Hagenfeldt (1989). 

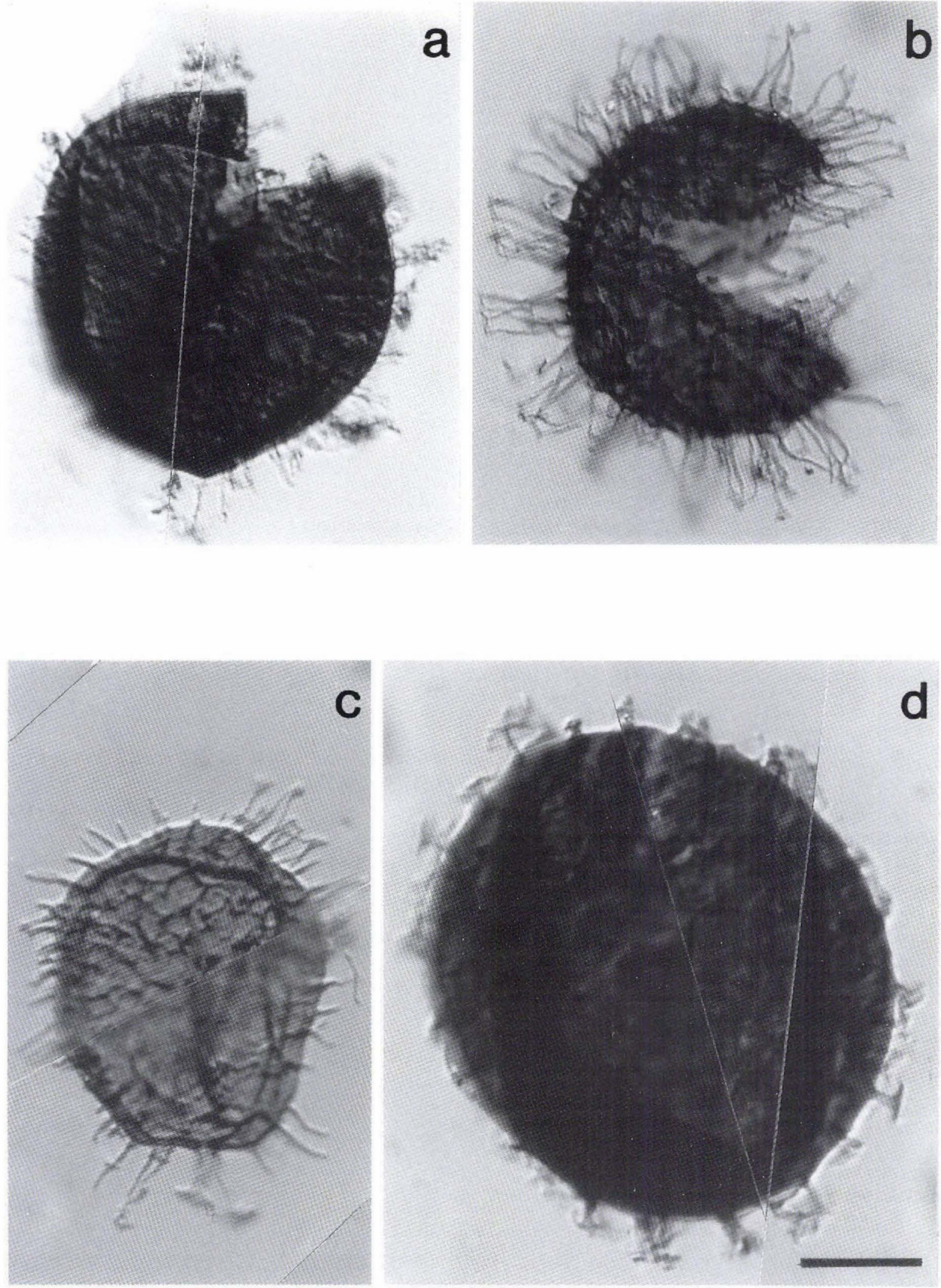


\section{Heliosphaeridium obscurum (Volkova, 1969) Moczydłowska, 1991}

Fig. 8c

Heliosphaeridium obscurum is a rare component in GGU sample 184002 (6 specimens; vesicle diameter 5-6 $\mu \mathrm{m}$; process length $1.5-2 \mu \mathrm{m})$. Synonymy and former occurrences were listed by Hagenfeldt (1991) and Moczydłowska (1991).

\section{Leiosphaeridia Eisenack, 1958 emend. Downie \& Sarjeant, 1963}

Fig. 11f

The genus Leiosphaeridia is here represented by sphaeromorphic acritarchs that are not identified to the specific level since morphological features are restricted to vesicle dimensions and relative wall thickness. The microfossils have circular to oval vesicles with smooth surface. The wall of the vesicle is generally sturdy and thick, and displays compression folds that are irregular both in shape and distribution. Excystment, when present, is by median split. The diameter of the vesicle ranges $\bar{x} 20-80 \mu \mathrm{m}$.

Specimens recorded in the Buen Formation (Fig. 3) may consist of solitary, discrete vesicles or more or less regular coenobial cell clusters of up to 8 cells (Fig. 11f). The latter are usually within the lower recorded diameter range of the discrete cells.

In general, microfossils attributed to Leiosphaeridia constitute one of the most common and abundant acritarch taxa in Neoproterozoic and Cambrian strata. On account of a lack of diagnostic features, an apparent stratigraphic range from Proterozoic to Tertiary has been recorded (Downie \& Sarjeant, 1964; Tappan, 1980; Lindgren, 1982a, b).

Fig. 12. Acritarchs from the Buen Formation, North Greenland. a, c, Skiagia ciliosa (Volkova, 1969) Downic, 1982 (morphotype A), specimen at a MGUH $21.560: \mathrm{Z} / 39-1$ from GGU sample 274796: G1; specimen at c, MGUH 21.562: Z/31 from GGU sample 274570: 1. b, Skiagia ciliosa (Volkova, 1969) Downie, 1982 (morphotype B), MGUH 21.561: Y/32 from GGU sample 184003: 1. d, Skiagia ciliosa (Volkova, 1969) Downie, 1982 (morphotype C), MGUH 21.563: Z/30 from GGU sample 274570: 1 . Bar under d represents $10 \mu \mathrm{m}$.

\section{Leiovalia tenera Kirjanov, 1974}

Fig. 11d

Leiovalia tenera is represented by 2 well-preserved specimens (Fig. 3). It consists of elongated, oval shaped flattened vesicles with smooth surface, often displaying thin compactional folds; the length ranges $87-90 \mu \mathrm{m}$, whereas the vesicle width ranges $34-40 \mu \mathrm{m}$. Previous occurrences were mentioned by Hagenfeldt (1989) and Eklund (1990).

\section{Lophosphaeridium dubium (Volkova, 1968) Moczydłowska, 1991 \\ Fig. $9 \mathrm{~g}$}

This consists of sphaeroidal vesicles tightly covered by small and short conical protuberances. Five recovered specimens indicate a vesicle diameter 19-36 $\mu \mathrm{m}$, whereas process length is $<1 \mu \mathrm{m}$. The species was transferred to the genus Lophosphaeridium by Moczydlowska (1991), who also listed synonymies and former occurrences (see also Hagenfeldt, 1989). The species is extremely rare in GGU samples 274570, 274571, 274796).

\section{Lophosphaeridium tentativum Volkova, 1968}

Fig. 9h

Lophosphaeridium tentativum is represented in 2 samples (Fig. 3) from the upper part of the sampled interval of the Buen Formation. It consists of spherical, flattened vesicles $11-45 \mu \mathrm{m}$ in diameter and covered with tightly arranged small granulae. For synonymy and previous occurrences see Hagenfeldt (1989) and Moczydłowska (1991).

\section{Lophosphaeridium truncatum Volkova, 1969}

Fig. $9 \mathrm{j}$

This species occurs in very small numbers in 3 samples (Fig. 3) of the Buen Formation. It consists of spherical vesicles $(N=6$, vesicle diameter $26-36 \mu \mathrm{m})$ covered by rounded, clavate, coarse grains and discrete granulae ( $<1-1 \mu \mathrm{m}$ in diameter). Previous occurrences and synonymies were given by Hagenfeldt (1989) and Moczydłowska (1991). 


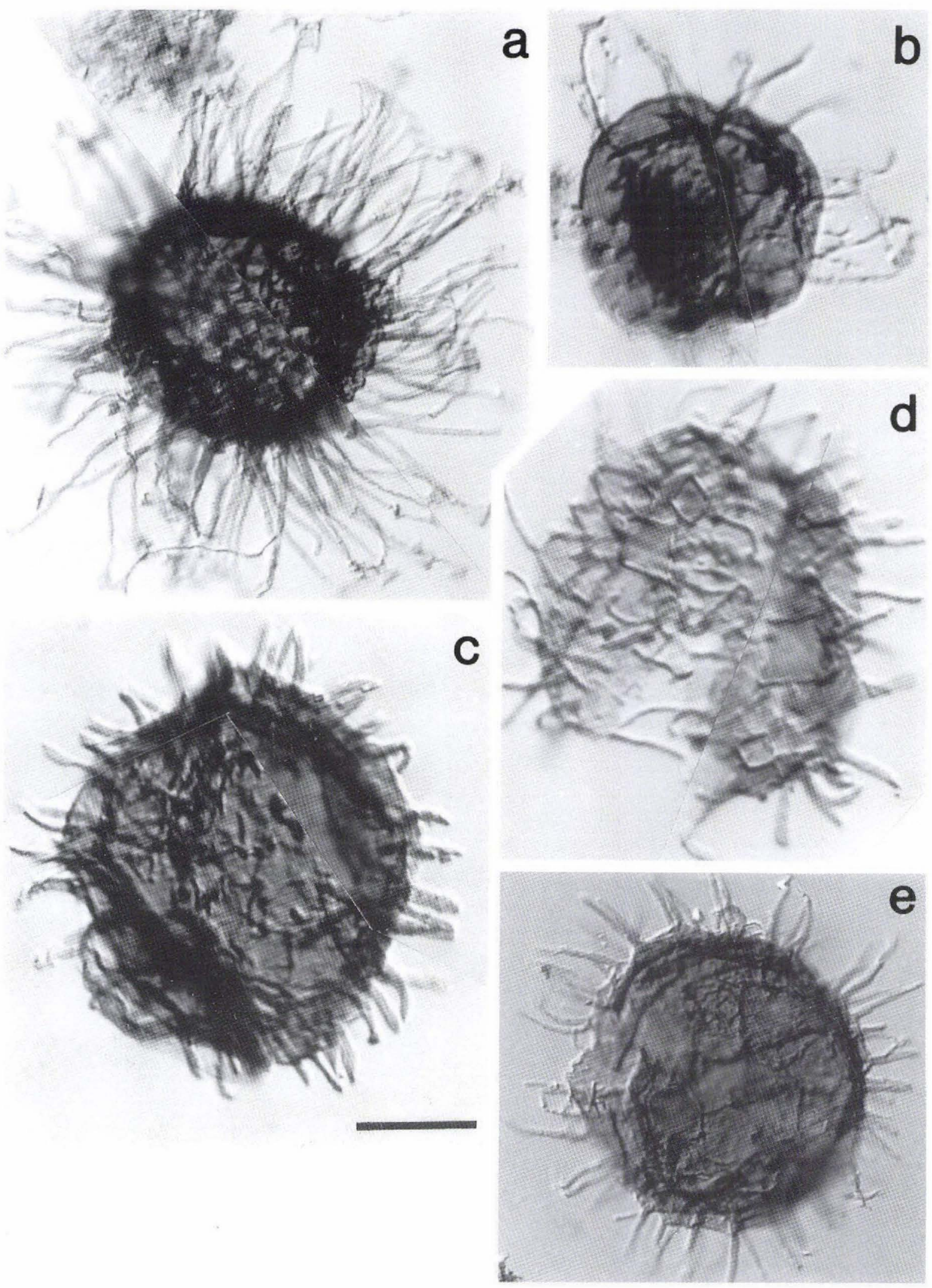




\section{Lophosphaeridium $\mathrm{sp}$.}

Fig. $9 \mathrm{i}$

Acritarchs attributed to Lophosphaeridium sp. consist of sphaeroidal vesicles ranging around $40 \mu \mathrm{m}$ in diameter which are densely covered by small sub-micron granulae.

\section{Multiplicisphaeridium dendroideum (Jankauskas, 1976) Jankauskas \& Kirjanov, 1979 \\ Fig. 11b, c}

Multiplicisphaeridium dendroideum, although found in 3 samples, is represented in the present material by 2 well-preserved specimens consisting of a central vesicle in communication with numerous $(>15)$ conical, dimorphic, evexate processes, often with ramified terminal portions. The overall dimensions are $18-26 \mu \mathrm{m}$, processes included, whereas the length and basal width of the processes is $3-4 \mu \mathrm{m}$ and $2-3 \mu \mathrm{m}$, respectively.

\section{Pterospermella Eisenack, 1972}

Fig. 9d

Acritarchs attributed to the genus Pterospermella Eisenack, 1972 are rare and consist of forms with a solid circular central body ranging $25-30 \mu \mathrm{m}$ in diameter surrounded by a translucent, $10-15 \mu \mathrm{m}$ wide extremely delicate ala. Various gradings in the density of the central body are observed.

\section{Retisphaeridium dichamerum Staplin, Jansonius \& Pocock, 1965}

Figs 9e, f, 10e

This species was recovered in generally small numbers from several samples of the Buen Formation. It consists of ellipsoidal to circular compressed vesicles

Fig. 13. Acritarchs from the Buen Formation, North Greenland. a, Skiagia ornata (Volkova, 1968) Downie, 1982, MGUH 21.564: F/29 from GGU sample 274796: G1. b, Elektoriskos sp. A., MGUH 21.565: K/33-4 from GGU sample 184002: 1. c, Globosphaeridium cerinum (Volkova) Moczydłowska, 1991, MGUH 21.566: R/25-3 from GGU sample 274570: 1. d, e, Skiagia orbiculare (Volkova, 1968) Downie, 1982, specimen at d, MGUH 21.567: T/50-4 from GGU sample 274795: A1; specimen at e, MGUH 21.568: X/42-3 from GGU sample 274571: G2. Bar under c represents $10 \mu \mathrm{m}$ for a-d; $15.6 \mu \mathrm{m}$ for e.
28-40 $\mu \mathrm{m}$ in diameter $(N=4)$ with psilate or very fine granular ornamentation displaying a transversal reticular pattern of folds. Synonymy and previous occurrences were given by Hagenfeldt (1989).

\section{Skiagia Downie, 1982}

Acritarchs attributed to the form-genus Skiagia form the bulk of the acritarch remains recovered from the Buen Formation. Synonymies and previous occurrences of the various species of this form-genus were treated by Downie (1982), Hagenfeldt (1989), Moczydłowska (1991) and Vidal \& Nystuen (1990b).

\section{Skiagia ciliosa (Volkova, 1969) Downie, 1982}

Fig. 12a-d

As is the case in former occurrences, three distinctive morphotypes of Skiagia ciliosa (Volkova, 1969) Downie, 1982, A, B and C, co-occur in discrete samples. Type A (Fig. 12a, c) has narrow process attachments and thin and slender process stems, whereas Skiagia ciliosa type B (Fig. 12b) possesses wider conical process attachments and processes stems, the processes being longer and provided with funnel-shaped apical ends. Shorter, less numerous and clearly evexate processes ornament the vesicle of morphotype C (Fig. 12d).

Acritarchs here referred to the three distinguished morphotypes (Fig. 12a-d) consist of circular to ovoidal vesicles (vesicle diameter: $N=100, \bar{x}=32.9 \mu \mathrm{m}$ ) with numerous cylindrical processes (process length: $N=$ $100, \bar{x}=3.9 \mu \mathrm{m}$ ). In the present, relatively abundant material, the processes appear hollow and are clearly isolated from the vesicle cavity by a plug. The proximal attachments of the processes are generally conical, whereas the apical portions are funnel-shaped.

\section{Skiagia compressa (Volkova 1968) Downie, 1982}

Fig. $14 \mathrm{~g}$

Rare acritarchs here attributed to Skiagia compressa possess an oval-shaped vesicle (vesicle diameter: $N=$ $35, \hat{x}=32.6 \mu \mathrm{m}$ ) that bears numerous, proximally wide and conical-shaped processes (process length: $N=35, \bar{x}$ $=5.7 \mu \mathrm{m}$ ), thus resulting in diagnostically 'crenulated' periphery. Distally, the processes are funnel-shaped. 


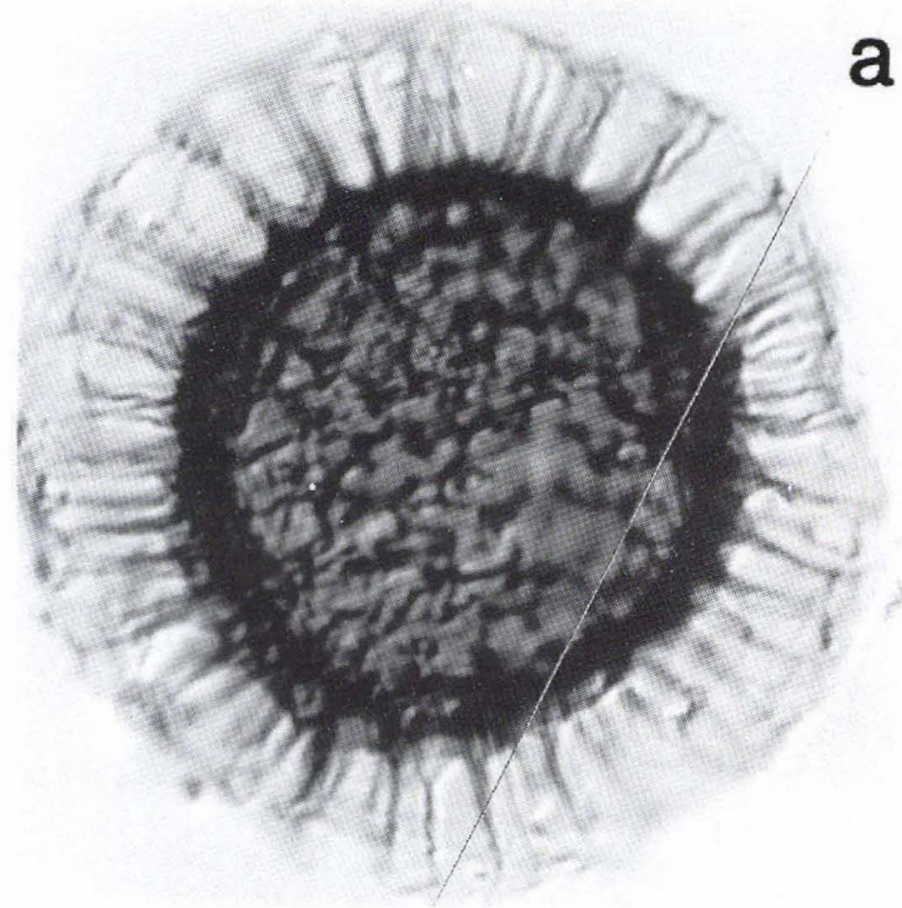

a thlowis b
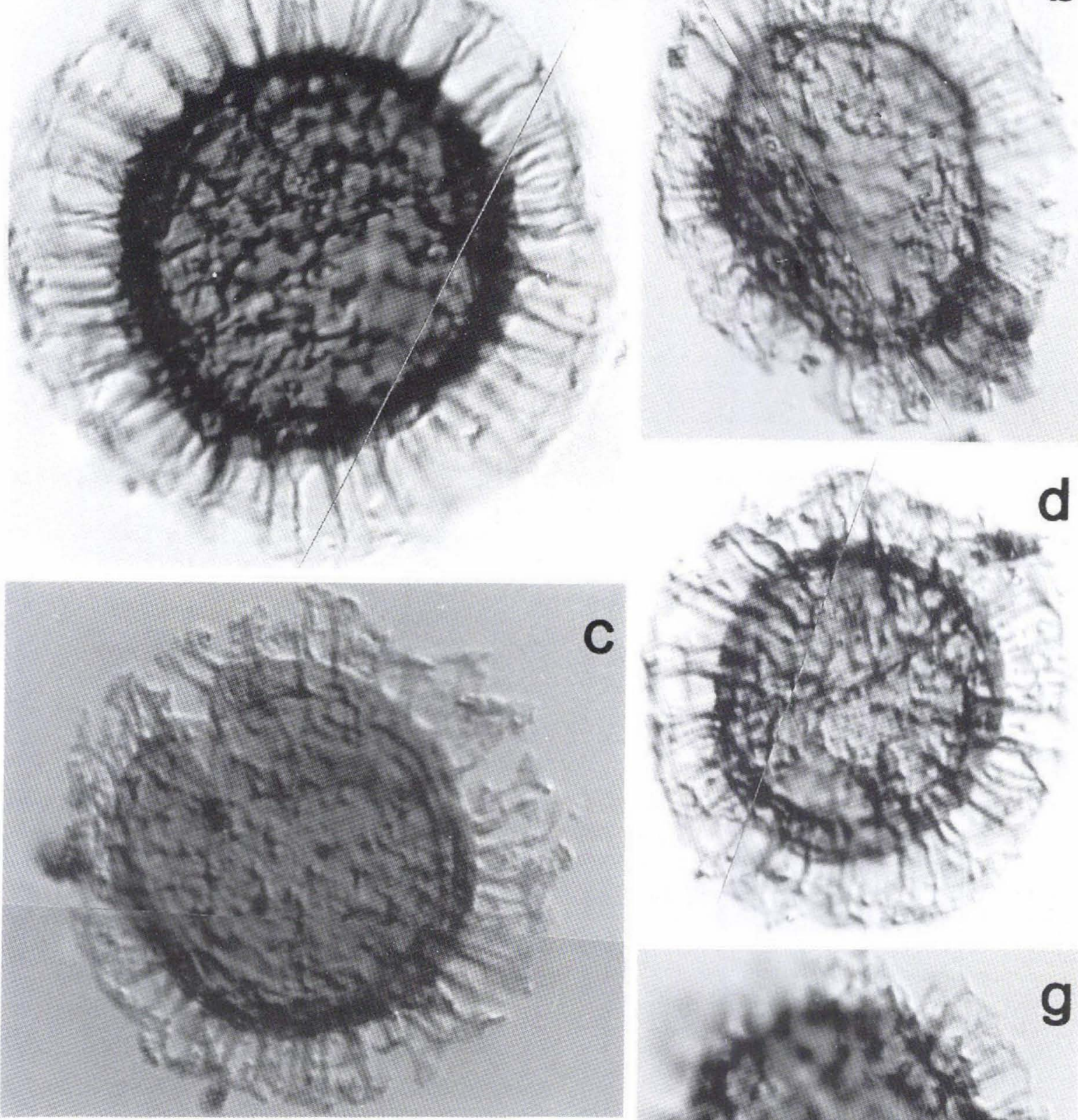

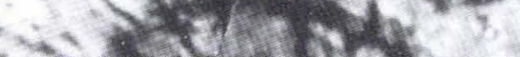

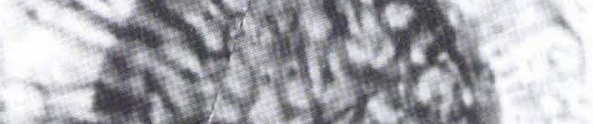

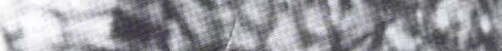

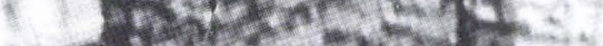

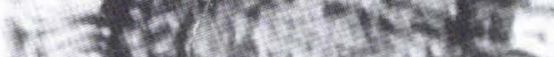

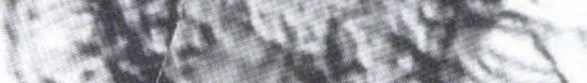

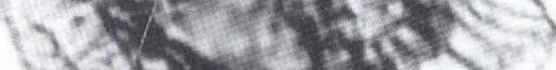

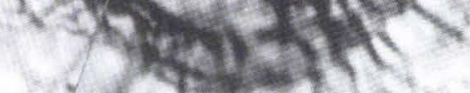

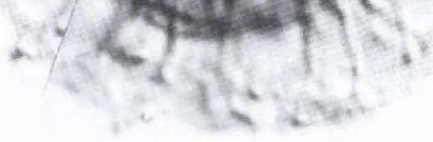

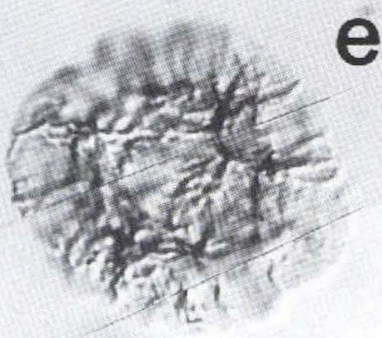

f
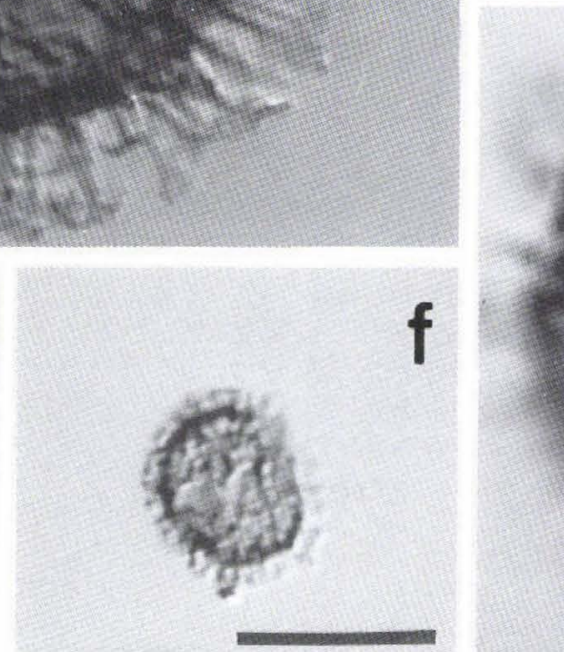

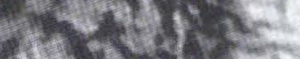
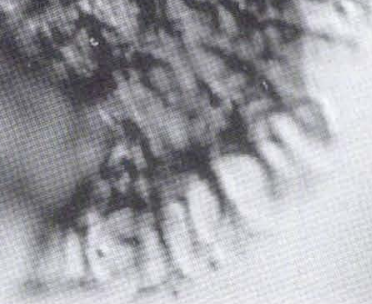
Skiagia orbiculare (Volkova, 1968)

Downie, 1982

Fig. 13d, e

Acritarchs attributed to Skiagia orbiculare are common in the Buen Formation (Fig. 3) and have ovoidal to spheroidal vesicles (vesicle diameter: $N=50, \bar{x}=31.7$ $\mu \mathrm{m}$ ) with numerous medium-length processes (process length: $N=50, \bar{x}=7.1 \mu \mathrm{m}$ ) that are slender, tapering from the proximal part along their total length. Their distal portions are funnel-shaped.

\section{Skiagia ornata (Volkova, 1968) Downie, 1982}

Fig. 13a

Skiagia ornata is an extremely abundant acritarch species in the Buen Formation (Fig. 3) that possesses an spheroidal vesicle (diameter: $N=140, \bar{x}=33.7 \mu \mathrm{m}$ ) with very numerous, long, slender cylindrical processes (process length: $N=140, \bar{x}=13.6 \mu \mathrm{m}$ ) that are widened proximally and distally (funnel-shaped).

\section{Skiagia scottica Downie, 1982}

Fig. 14a-d

Together with $S$. ornata, this species is among the most abundantly occurring acritarchs in the Buen Formation (Fig. 3). It has a spheroidal to ovoidal vesicle (vesicle diameter: $N=140, \bar{x}=27.5 \mu \mathrm{m}$ ) with numerous, tightly arranged processes that are of variable length (process length: $N=140, \vec{x}=6.1 \mu \mathrm{m}$ ), slender and cylindrical, proximally slightly widened and distally opened into a wide funnel-shape, being often attached to one another at the distal funnel-shaped ends.

Fig. 14. Acritarchs from the Buen Formation, North Greenland. a-d, Skiagia scottica Downie, 1982, specimen at a, MGUH 21.569: Q/26-3 from GGU sample 184004-B; specimen at b, MGUH 21.570: Z/29 from GGU sample 274796: G1; specimen at c, MGUH 21.571: O/51-4 from GGU sample 274571: G2; specimen at d, MGUH 21.572: L/34-2 from GGU sample 274797: G1. e, Fimbriaglomerella membranacea (Kirjanov, 1974) Moczydlowska \& Vidal, 1988, MGUH 21.573: Z/29-1 from GGU sample 274798: A1. f, Fimbriaglomerella minuta (Jankauskas, 1979) Moczydłowska \& Vidal, 1988, MGUH 21.574: Z/49-3 from GGU sample 274796: G1. g, Skiagia compressa (Volkova, 1968) Downie, 1982, MGUH 21.575: K/48-2 from GGU sample 274796: G1. Bar under f represents $10 \mu \mathrm{m}$ for $\mathrm{a}-\mathrm{f} ; 11 \mu \mathrm{m}$ for $\mathrm{g}$.
Tasmanites bobrowskae Ważyńska, 1967

Fig. 15b-c

Rare organic-walled spheroidal microfossils placed here are often compressed, having vesicles which are circular to oval in outline $(N=7, \bar{x}=90.4 \mu \mathrm{m})$ and possessing a thick vesicle wall perforated by irregularly distributed large pores. For synonymy and previous occurrences see Hagenfeldt (1989) and Moczydłowska (1991).

\section{Tasmanites tenellus Volkova, 1968 Fig. 15a}

This species is very rare in the present material. It comprises organic-walled microfossils having circular to oval compressed vesicles (vesicle diameter: $N=7, \bar{x}=$ $90 \mu \mathrm{m}$ ) with a thin vesicle wall perforated by small, irregularly distributed pores. Synonymy and occurrences were recently listed by Hagenfeldt (1989) and Moczydlowska (1991).

\section{Tasmanites volkovae Kirjanov, 1974 Fig. 15d}

This is extremely rare in samples from the Buen Formation. The circular, organic-walled vesicle (vesicle diameter: $60-70 \mu \mathrm{m}$ ) possesses a thick perforated wall with abundant, regularly distributed pores located in funnel-like wall depressions, a diagnostic feature that results in the irregular periphery of the thick vesicle wall. For synonymy and previous occurrences see Hagenfeldt (1989) and Moczydłowska (1991).

\section{Trachysphaeridium timofeevi Vidal, 1976}

Trachysphaeridium timofeevi is a rare component in samples of the Buen Formation (Fig. 3). The ovoidal to ellipsoidal, walled and scabrate sculptured vesicle ranges $50-62 \mu \mathrm{m}$ by $20-40 \mu \mathrm{m}$. Previous occurrences were listed by Hagenfeldt (1989).

Various tubular sheaths, possibly cyanobacterial, occur in the investigated samples of the Buen Formation (Fig. 9k). The sheaths are of quite variable length and range in width from $2-10 \mu \mathrm{m}$. These fossils were recorded in variable numbers in most processed samples. 

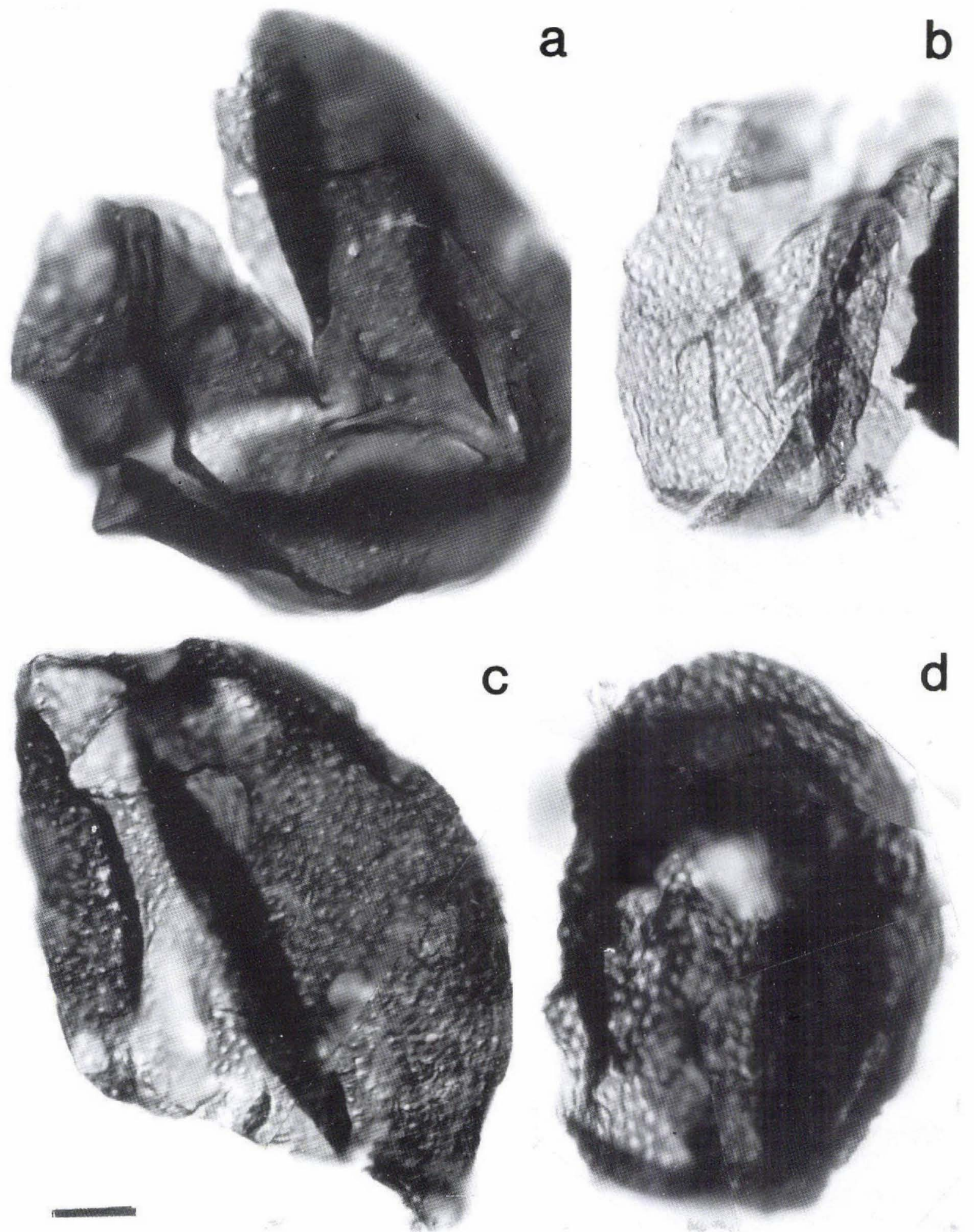

Fig. 15. Acritarchs from the Buen Formation, North Greenland. a, Tasmanites tenellus Volkova, 1968, MGUH 21.576: J/40-2 from GGU sample 274800: A1. b, c, Tasmanites bobrowskae Ważyńska, 1967, specimen at b, MGUH 21.577: Z/39-4 from GGU sample 274797: G1; specimen at c, MGUH 21.578: C/33-1 from GGU sample 274797: G1. d, Tasmanites volkovae Kirjanov, 1974, MGUH 21.579: Z/43 from GGU sample 274797: G1. Bar under c represents $10 \mu \mathrm{m}$ for a-b, d; $14 \mu \mathrm{m}$ for $\mathrm{c}$. 


\section{Acknowledgements}

G. Vidal acknowledges grant support from the Swedish Natural Science Research Council (NFR). Jon R. Ineson (Dan- marks Geologiske Undersøgelse) is thanked for discussion of Buen environments and for providing Fig. 2.

\section{References}

Awramik, S. M., McMenamin, D. S., Yin Chongyu, Zhao Ziqiang, Ding Qixiu \& Zhang Shusen 1985: Prokaryotic and eukaryotic microfossils from a Proterozoic/Phanerozoic transition in China. Nature 315, 655-658.

Baudet, D., Aitken, J. D. \& Vanguestaine, M. 1989: Palynology of uppermost Proterozoic and lowermost Cambrian formations, central Mackenzie Mountains, northwestern Canada. Can. J. Earth Sci. 26, 129-148.

Bergström, J. \& Peel, J. S. 1988: Lower Cambrian trace fossils from northern Greenland. Rapp. Grønlands geol. Unders. 137, 43-53.

Berry, W. B. N., Wilde, P. \& Quinby-Hunt, M. S. 1989: Paleozoic (Cambrian through Devonian) anoxitropic biotopes. Palaeogeog. Palaeoclimatol. Palaeoecol. 74, 3-13.

Blaker, M. R. 1988: A new genus of nevadiid trilobite from the Buen Formation (Early Cambrian) of Peary Land, central North Greenland. Rapp. Grønlands geol. Unders. 137, 33-41.

Bryant I. D. \& Pickerill, R. K. 1990: Lower Cambrian trace fossils from the Buen Formation of central North Greenland: preliminary observations. Rapp. Grønlands geol. Unders. 147, 44-62.

Butterfield, N. J. 1990: Organic preservation of non-mineralizing organisms and taphonomy of the Burgess Shale. Paleobiology 16, 272-286.

Butterfield, N. J., Knoll, A. H. \& Swett, K. 1988: Exceptional preservation of fossils in an Upper Proterozoic shale. Nature 334, 424-427.

Conway Morris, S. 1987: The search for the PrecambrianCambrian boundary. Amer. Scientist 75, 156-167.

Conway Morris S. \& Peel, J. S. 1990: Articulated halkieriids from the Lower Cambrian of North Greenland. Nature 345, 802-805.

Conway Morris, S., Peel, J. S., Higgins, A. K., Soper, N. J. \& Davis, N. C. 1987: A Burgess Shale-like fauna from the Lower Cambrian of North Greenland. Nature 326, 181-183.

Crimes, T. P. 1987: Trace-fossils and the Precambrian-Cambrian boundary. Geol. Mag. 124, 97-119.

Dale, B., 1977: New observations on Pterdinium faeroensis Paulsen (1905), and classification of small orthoperidinioid dinoflagellates. Brit. Phycol. J. 2, 241-253.

Dawes, P. R. 1976: Precambrian to Tertiary of northern Greenland. In Watt, W. S. \& Escher, A. (ed.) Geology of Greenland, 248-303. Copenhagen: Geol. Surv. Greenland.

Downie, C. 1973: Observations on the nature of the acritarchs. Palaeontology 16, 239-259.

Downie C. 1982: Lower Cambrian acritarchs from Scotland,
Norway, Greenland and Canada. Trans. Roy. Soc. Edinburgh, Earth Sci. 72, 257-282.

Downie, C. \& Sarjeant, W. A. S. 1964: Bibliography and index of fossil dinoflagellates and acritarchs. Mem. Geol. Soc. Amer. 94, 180 pp.

Eklund, C. 1990: Lower Cambrian acritarch stratigraphy of the Bårstad 2 core, Östergötland, Sweden. Geol. Fören. Stockholm Förhandl. 112, 19-44.

Eppley, R. W., Rogers, J. N. \& McCarthy, J. J. 1969: Half saturation constants for uptake of nitrate and ammonium by marine phytoplankton. J. Phycol. 5, 912-920.

Evitt, W. R. 1985: Sporopollenin dinoflagellate cysts. Their morphology and interpretation, 333 pp. Texas: Amer. Assoc. Stratigraphic Palynologists Foundation.

Fombella, M. A. 1977: Acritarcos de edad Cambrico Medioinferior de la provincia de Léon, España. Rev. Española Micropaleont. 9:1, 115-124

Gamez, J. A., Nieto, C., Gozalo, R., Liñán, E. Mandado, J. \& Palacios, T. (in press): Bioestratigrafía y evolución del Cambrico de Borobia, Provincia de Soria. Cadenas Ibéricas Orientales. Cuad. lab. xeologico de Laxe 16, 251-271.

Hagenfeldt, S. 1989: Lower Cambrian acritarchs from the Baltic Depression and south-central Sweden, taxonomy and biostratigraphy. Stockholm Contr. Geol. 41, 1-176.

Higgins, A. K., Ineson, J. R., Peel, J. S., Surlyk, F. \& Sønderholm, M. 1991: Lower Palaeozoic Franklinian Basin of North Greenland. Bull. Grønlands geol. Unders. 160, 71139.

Jankauskas, T. V. 1979: [Middle Riphean microbiota from the southern Urals and the Bashkirian Urals.] Akad. Nauk SSSR 248, 190-193. [In Russian.]

Jux, U. 1971: Über den Feinbau der Wandungen einiger paläozoischer Baltisphaeridiacean. Palaeontographica B 136, 115128.

Jux, U. 1975: Phytoplankton aus dem mittleren Oberdevon (Nehden-Stufe) des südwestlichen Bergischen Landes (Rheinisches Schifergebirge). Palaeontographica B 149, 113-138.

Keller, B. M., \& Jankauskas, T. V. 1980: [Microfossils from the Riphean stratotype of the southern Urals.] Akad. Nauk SSSR 12, 58 67. [In Russian.]

Knoll, A. H. 1984: Microbiotas of the Precambrian Hunnberg Formation, Nordaustlandet, Svalbard. J. Paleont. 58, 131162.

Knoll, A. H. 1985: The distribution and evolution of microbial life in the Late Proterozoic Era. Ann. Rev. Microbiol. 39, 391-417.

Knoll, A. H. \& Calder, S. 1983: Microbiotas of the Late 
Precambrian Ryss $ø$ Formation, Nordaustlandet, Svalbard. Palueontology 26, 467-496.

Knoll, A. H. \& Ohta, Y. 1988: Microfossils in metasediments from Prins Karls Forland, western Svalbard. Polar Res. 6, 59-67.

Knoll, A. H. \& Swett. K. 1985: Micropalaeontology of the late Proterozoic Veteranen Group, Spitsbergen. Palaeontology 28, 451-473.

Knoll A. H. \& Swett, K. 1987: Micropaleontology across the Precambrian-Cambrian boundary in Spitsbergen. $J$. Paleont. 61, 898-926.

Knoll, A. H., Swett, K. \& Mark, J. 1991: Paleobiology of a Neoproterozoic tidal flat/lagoonal complex: the Draken Conglomerate Formation, Spitsbergen. J. Paleont. 65, 531570 .

Lindgren, S. 1982a: Taxonomic review of Leiosphaeridia from the Mesozoic and Tertiary. Stockholm Contr. Geol. 38, 21-33.

Lindgren, S. 1982b: Algal coenobia and leiospheres from the Upper Riphean of the Turukhansk region, eastern Siberia. Stockholm Contr. Geol. 38, 35-45.

Mansuy, C., \& Vidal, G. 1983: Late Proterozoic Brioverian microfossils from France; taxonomic affinity and implications of plankton productivity. Nature 302, 606-607.

Moczydłowska, M. 1988: New Lower Cambrian acritarchs from Poland. Rev. Palaeobot. Palynol. 54, 1-10.

Moczydłowska, M. 1991: Acritarch biostratigraphy of the Lower Cambrian and the Precambrian-Cambrian boundary in southeastern Poland. Fossils \& Strata 29, $127 \mathrm{pp}$.

Moczydłowska, M. \& Vidal, G. 1986: Lower Cambrian acritarch zonation in southern Scandinavia and southeastern Poland. Geol. Fören. Stockholm Förhandl. 108, 201-223.

Moczydłowska, M. \& Vidal, G. 1988: Early Cambrian acritarchs from Scandinavia and Poland. Palynology 12, 1-10.

Moczydłowska, M. \& Vidal, G. 1991: Phytoplankton from the Lower Cambrian Lxeså Formation on Bornholm, Denmark: biostratigraphy and palacoenvironmental constraints. Geol. Mag. 129, 17-40.

Moorman, M. A. 1974: Microbiota of the Late Proterozoic Hector Formation, southwestern Alberta, Canada. J. Paleont. 48, 524-539.

Palacios, T. 1989: Microfosiles de pared organica del Proterozoico Superior (Región Central de la Península Ibérica). Mem. Mus. Paleont. Univ. Zaragoza 3, 91 pp.

Palacios, T. \& Vidal, G. 1992: Lower Cambrian acritarchs from northern Spain: the Precambrian-Cambrian boundary and biostratigraphic implications. Geol. Mag. 129, 1-16.

Palmer, A. R. \& Peel, J. S. 1979: New Cambrian faunas from Peary Land, eastern North Greenland. Rapp. Gronlands geol. Unders. 91, 29-36.

Pearson, D. A. 1984: Pollen/Spore Color Standard. Version 2. Phillips Petroleum Company, Exploration Projects Section.

Peel, J. S. 1982: The Lower Paleozoic of Greenland. Mem. Can. Soc. Petrol. Geol. 8, 309-330.

Peel, J. S. 1988: Spirellus and related helically coiled microfossils (cyanobacteria) from the Lower Cambrian of North Greenland. Rapp. Gronlands geol. Unders. 137, 5-32.
Peel, J. S. 1990: Studying the early history of life in Greenland. Rapp. Gronlands geol. Unders. 148, 54-56.

Peel, J. S. \& Christie, R. L. 1982: Cambrian-Ordovician platform stratigraphy: correlations around Kane Basin. Meddr Gronland Geosci. 8, 117-135.

Peel, J. S., Conway Morris, S. \& Ineson, J. R. 1992: A second glimpse of Early Cambrian life: new collections from Sirius Passet, North Greenland. Rapp. Gronlands geol. Unders. 155, 48-50.

Pjatiletov, V. G. \& Rudavskaya, V. A. 1985: [Acritarchs from the Yudomian Complex.] In Sokolov, B. S. \& Ivanovsky, A. B. (ed.) Vendian System 1, Palaeontoloqy, 151-158. Moscow. [In Russian.]

Poulsen, V. 1974: Olenellacean trilobites from eastern North Greenland. Bull. geol. Soc. Denmark 23, 79-101.

Staplin, F. L., Bailey, N. J. L., Pocock, S. A. \& Evans, C. R. 1973: Diagenesis and metamorphism of sedimentary organic matters. Unpublished paper presented at the American Association of Petroleum Geology Symposium, Anaheim. California, 1973 (not seen; referred to in Venkatachala, B. S. 1981, see below).

Surlyk, F. 1992: Tectonostratigraphy of North Greenland. Bull. Gronlands geol. Unders. 160, 25-47.

Tappan, H. 1980: The paleobiology of plant protists, $1028 \mathrm{pp}$. San Francisco: Freeman \& Co.

Venkatachala, B. S. 1981: Differentiation of amorphous organic matter types in sediments. In Brooks, J. (ed.) Organic maturation studies and fossil fuel exploration, 177-200. London: Academic Press.

Vidal, G. 1988: A palynological preparation method. Palynology 12, 215-220.

Vidal, G. 1990: Giant acanthomorph acritarchs from the Upper Proterozoic in southern Norway. Palaeontology 33, 287298.

Vidal, G. \& Nystuen, J. P. 1990a: Micropalaeontology, depositional environment and biostratigraphy of the Upper Proterozoic Hedmark Group, southern Norway. Amer. J. Sci. 290A, 170-211.

Vidal, G. \& Nystuen, J. P. 1990b: Lower Cambrian acritarchs and Proterozoic-Cambrian boundary in southern Norway. Norsk Geol. Tidskr. 70, 191-222.

Vidal, G. \& Peel, J. S. 1984: Acritarch biostratigraphy of the Lower Cambrian of Greenland. In Armands, G. \& Schager, S. (ed.) Abstr. I6th Nordisk Geologiske Vintermötet Stockholm. Meddel. Stockholm Univ. Geol. Inst. 255, 234 only.

Vidal, G. \& Peel, J. S. 1988: Acritarchs from the Buen Formation (Lower Cambrian), North Greenland. Rapp. Gronlands geol. Unders. 137, 54 only.

Volkova, N. A. 1968: [Acritarchs from Precambrian and Cambrian deposits in Estonia.] In Keller, B. M. (ed.) [Problematics of Riphean and Cambrian of the Russian Platform, Urals and Kazakhstan], 8-36. Moscow: Nauka. [In Russian.] Volkova, N. A. 1969a: [Distribution of acritarchs in the northeastern Poland.] In Rozanov, A. Yu. et al. [Tommotian Stage and the Cambrian lower boundary problem], 74-76. Moscow: Nauka. [In Russian.]

Volkova, N. A. 1969b: [Acritarchs of the north-western Rus- 
sian platform.] In Rozanov, A. Yu. et al. [Tommotian Stage and the Cambrian lower boundary problem], 224-236. Moscow: Nauka. [In Russian.]

Volkova N. A. 1981a: Distribution of acritarchs in sections of northeastern Poland. In Raaben M. E. (ed.) The Tommotian Stage and the Cambrian lower boundary problem, 86-88. New Delhi: Amerind Publishing Co.

Volkova, N. A. 1981b: Acritarchs of the northwestern Russian Platform. In Raaben, M. E. (ed.) The Tommotian Stage and the Cambrian lower boundary problem, 259-273. New Delhi: Amerind Publishing Co.

Volkova, N. A., Kirjanov, V. V., Piskun, L. V., Pashkeviciene, L. T. \& Jankauskas, T. V. 1979: [Plant microfossils.] In Keller, B. M. \& Rozanov, A. Yu. (ed.) [Upper Precambrian and Cambrian palaeontology of the East-European Platform], 4-38. Moscow: Nauka. [In Russian.]
Volkova, N. A., Kirjanov, V. V., Piskun, L. V., Pashkeviciene, L. T. \& Jankauskas, T. V. 1983: Plant microfossils. In Urbanek, A. \& Rozanov, A. Yu. (ed.) Upper Precambrian and Cambrian palaeontology of the East-European Platform, 5-46. Warszawa: Wydawnictwa Geologiczne.

Yin Leiming 1985: Microfossils of the Doushantuo Formation in the Yangtze Gorge district, and Western Australia. Proc. Roy. Soc. Victoria 83, 211-234.

Zang Wenlong 1988: Ediacaran plankton. Abstr. 7th International Palynological Congress, Brisbane 1988, 184 only.

Zang Wenlong, \& Walter, M. R. 1989: Latest Proterozoic plankton from the Amadeus Basin in Central Australia. Nature 337, 642-645. 
